\title{
EVOLUÇÃO TECTÔNICA DO CINTURÃO DOM FELICIANO NO ESCUDO SUL-RIO-GRANDENSE: PARTE I - UMA CONTRIBUIÇÃO A PARTIR DO REGISTRO GEOLÓGICO
}

\author{
LUÍS ALBERTO DÁ VILA FERNANDES ${ }^{* * * *}$; RUALDO MENEGAT****; ANTÔNIO FLÁVIO UBERTI \\ COSTA $^{* * * * *}$; EDINEI KOESTER $* * * * * * ;$ CARLA CRISTINE PORCHER $*$; ANDREIA TOMMASI ${ }^{* * * * * * *}$; GUSTAVO \\ KRAEMER $* * * * ;$ GILBERTO EMÍLIO RAMGRAB ${ }^{* * *}$ \& EDUARDO CAMOZZATO
}

\begin{abstract}
A reappraisal of the geological basis of a Plate Tectonics model proposed for the tectonic evolution of the Dom Feliciano Belt in the Sul-rio-grandense Shield is presented under the light of a research programme in geology. Folio wing the presentation of a synthesis about the nature and structural characteristics of each geotectonic unit recognised, the main geotectonic models presented for this belt are discussed under the conceptual and substantive point of view. A discussion about the nature and advantages of an atualistic model for this belt is presented, being followed by a criticai evaluation of the geochronological and geophysical data recently obtained, the latter in the second part of this article.
\end{abstract}

Keywords: tectonic evolution, Dom Feliciano Belt, Southern Brazil, geològic record

RESUMO As bases geológicas de um modelo atualista anteriormente proposto para a evolução tectônica do Cinturão Dom Feliciano no Escudo Sul-rio-grandense são presentemente revisadas e discutidas sob a luz de um programa de pesquisas em geologia. Após a apresentação de uma síntese da natureza e características estruturais de cada uma das unidades geotectônicas reconhecidas, são discutidos os principais modelos geotectônicos recentemente apresentados para o Escudo Sul-rio-grandense, sob o ponto de vista conceituai e substantivo. Segue-se uma discussão acerca da natureza e vantagens de modelos baseados na Tectônica de Placas, finalizando-se a contribuição com uma avaliação crítica do significado dos dados geocronológicos e geofisicos recentemente obtidos para o cinturão, estes celtimos na segunda parte do artigo.

INTRODUÇÃO: PROGRAMAS DE PESQUISA PARA O ESCUDO SUL-RIO-GRANDENSE No presente século, quatro programas de pesquisa estruturam-se para o estudo do Escudo Sul-rio-grandense: a) o mineiro-geognóstico, de 1909 a 1940; b) o mineiro-epirogênico, de 1941 a 1958; c) o geossinclinal-metassomático, de 1959 a 1977; e c) o plaquista, desenvolvido desde 1978 (cf. Menegat 1992, Menegat \& Fernandes 1992,1993b). O principal modelo do período geognóstico foi desenvolvido pelo engenheiro de minas Paulino de Carvalho (1932), o qual seguia rigidamente os preceitos da layer cake stratigraphy, inaugurada por Alfred G. Werner ainda no século XVIII. Carvalho (1932) foi quem cunhou o termo Escudo Sul-rio-grandense, com significado geomorfológico, substituindo a expressão 'complexo cristalino', com sentido estratigráfico, dada por Branner (1919). O segundo programa de pesquisas representou um renascimento da geologia no estado, no qual foram desenvolvidos, demarcadamente por Viktor Leinz, et al. (1941) e, depois, por Beurlen \& Martins (1956), modelos que procuravam explicar o registro geológico do Escudo em termos de movimentos epirogênicos e perturbações locais. Esses modelos, que definem o Escudo como uma entidade tectônica, resgatando o sentido originalmente utilizado por Branner (1919) são bastante desconhecidos pela cultura geológica brasileira e riograndense. Já o programa geossinclinal-metassomático, relacionado com o surgimento da Escola de Geologia em 1958, iciano, Brasil meridional, registro geológico

foi desenvolvido por Tessari \& Picada (1966), resultando no desenvolvimento de um modelo geossinclinal que se tornou o primeiro grande paradigma da Geologia do Rio Grande do Sul (no sentido proposto por Kuhn,1989). Embora os modelos do período plaquista tivessem adotado parâmetros totalmente diferentes, a concepção de Tessari \& Picada (1966) exerceu influência tanto no aspecto substantivo, ao propor a compartimentação do Escudo com base em conceitos geossinclinais, quanto no metodológico, ao considerar o par petrologia/ tectônica fundamental para a proposição de modelos geotectônicos.

O período plaquista iniciou-se em 1978, através da mudança radical de paradigma empreendida por Ribeiro \& Fantinel (1978), que organizaram os dados do Escudo Sul-riograndense em termos dos preceitos derivados da Teoria da Tectônica de Placas. Entretanto foi Fragoso-César (1980) quem apresentou o primeiro modelo completo, erigido com base em critérios paleogeográficos. Este foi claramente influenciado pelo modelo geossinclinal, mas incorporou elementos fundamentais que são as correlações geotectônicas continentais, empreendidas basicamente por Hasuí et al. (1975). Já as correlações intercontinentais foram definidas em Porada (1979), que propôs um modelo compatível com o registro geológico formado pela convergência entre o Cráton do Rio de La Plata, na América do Sul, e o Kalahari, na çfrica. No entanto, foi somente uma década mais tarde que o primeiro

\footnotetext{
* CPGq-Depto de Geologia -IG/UFRGS (Ferna@vortex.ufrgs.br)

** Pesquisador do CNPq

*** Serviço Geológico do Brasil (CPRM)

**** Depto de Paleontologia e Estratigrafia -IG/UFRGS

***** Curso de Pós-Graduação em Geociências- IG/UFRGS

****** Lab. Tectonophysique-Université de Montpellier II (Fr)
} 
modelo geotectônico de natureza 'tridimensional' foi proposto (Tommasi \& Fernandes 1990). Nesse foram considerados pela primeira vez os critérios estruturais (cinemática da deformação) para a sistematização dos mais diferentes litodemas em associações petrotectônicas.

Entretanto, nos celtimos três anos, uma nova tendência tem sido apresentada por programas de pesquisa que não consideram os conceitos da Tectônica de Placas como fundamentais na proposição de modelos geotectônicos para o pré-Cambriano do Escudo Sul-rio-grandense. Tais programas fazem parte de concepções com marcantes diferenças substantivas e metodológicas. Enquanto as primeiras são mais facilmente reconhecidas pela literatura, pois tratam da configuração do modelo, as de cunho metodológico ainda não tem merecido a devida atenção. Pode-se demonstrar, no entanto, que tanto os critérios substantivos quanto os metodológicos são indispensáveis para o estabelecimento de premissas para a escolha de programas de pesquisa, e por consequência, dos modelos derivados ( $c f$. Lakatos 1974).

Esse debate tem permanecido ocluso pelo fato da literatura ter-se dedicado de forma fragmentária à investigação de aspectos bastante específicos das rochas ou associações de rochas cuja posição estratigráfica e contexto geológico regional ainda não estão satisfatoriamente bem estabelecidos. Isto significa que, na realidade, o estabelecimento de modelos e programas de pesquisa na geologia tem influenciado muito pouco os trabalhos e, por isso, o debate metodológico aparentemente não tem importância. Pelo contrário, a tese aqui defendida é a de que a ausência de estratégias de pesquisa, que tem presidido muitos trabalhos publicados em quantidade sem precedente na história da Geologia do RS (cf. Referências Bibliográficas), tem servido mais para confundir a incipiente sistematização alcançada, do que para contribuir na elucidação da história da evolução geológica da região. Desta forma, esses trabalhos parecem constituir um programa de pesquisa que propugna a ausência de métodos ou da elegia pura e simples da técnica. Algumas contribuições, por exemplo, tem se utilizado de métodos sofisticados como estudos isotópicos, mas que por estarem alicerçados em bases geológicas muito restritas, tem o seu alcance interpretativo drasticamente reduzido. De qualquer modo, utilizam-se dos mesmos para testar modelos capazes de sistematizar uma série de técnicas interdisciplinares e aparentemente, conseguem refutá-los. No entanto, os modelos propostos em substituição apresentam um tal grau de complexidade, que anulam a sua capacidade preditiva e explicativa. Como consequência, os trabalhos resumem-se, cada vez mais, aos aspectos empíricos restritos, em vista da incapacidade de progressão dos modelos, estabelecendo-se um círculo vicioso que é, em si, tomado como um 'programa de pesquisa'. Esse bloqueio, induz uma falta de discussão sobre o assunto.

Exemplos de concepções como essas são os modelos de orogenia 'Ensiálica', como aqueles baseados na 'Tectônica de Terrenos', e, mais recentemente, os modelos de 'Plumas Mantélicas'. Enquanto as proposições dos primeiros não apresentam sequer as evidências geológicas e estruturais necessárias para a sua sustentação, os celtimos, resultantes de metodologias inconsistentes, parecem refletir certas tendências esboçadas na literatura internacional ou, talvez mesmo, a resistência da comunidade geológica local em utilizar-se de arcabouços conceituais metodologicamente consistentes e universalmente aceitos (e.g. Tectônica de Placas). Isso levou à proposição de uma gama variada de modelos de comparti- mentação tectônica, muitos dos quais, em função da sua restrita base geológica e insuficiente organização do registro, tendem, além de ser bastante efémeros, a causar uma profusão desnecessária e inadequada de denominações tectônicas e estratigráficas (eg. Cinturões Dom Feliciano, Vila Nova, Tijucas, etc.). Além disso, a pobreza de exposição das rochas no Escudo Sul-rio-grandense; a complexidade geológica, determinada pelas rápidas e frequentes variações de nível crustal, controladas por falhas, em pequenas distâncias; a falta de tradição no desenvolvimento de trabalhos de campo e determinação estratigráfica; a escassez de dados geológicos e, principalmente, geofísicos, capazes de fornecer informações sobre as características das rochas em profundidade; têm contribuído, sobremaneira, para o estabelecimento do quadro atual.

$\mathrm{Na}$ tentativa de contribuir para a elucidação da história da evolução geológica do pré-Cambriano do RS, a primeira parte este trabalho apresenta uma proposta de compartimentação tectônica baseada em dados geológicos e geofísicos que se utiliza do arcabouço conceituai fornecido pela Tectônica de Placas. Para tanto, apresentam-se as diversas associações petrotectônicas, estabelecidas a partir de critérios estratigráficos, estruturais, petrológicos e geocronológicos, que têm servido para a construção de modelos plaquistas. Cada associação petrotectônica é enunciada em termos de uma síntese da sua geologia baseada em mapeamento lito-estrutural de detalhe em áreas selecionadas. Esse modelo, que se constitui principalmente na atualização de uma proposta anteriormente apresentada por Tommasi e Fernandes (1990) e Fernandes et al. (1992a) é então discutido sob a luz dos dados geocronológicos e petrológicos, que vêm sendo recentemente obtidos para as rochas do Escudo Sul-rio-grandense. $\mathrm{Na}$ segunda parte dessa contribuição, após uma apresentação dos problemas metodológicos e epistemológicos relacionados à utilização de modelos no desenvolvimento de um programa de pesquisas em geologia, são discutidas as características principais dos modelos plaquistas em termos da sua capacidade preditiva e explicativa. No final do trabalho uma discussão metodológica e conceituai sobre os diversos programas de pesquisa para a construção de modelos é delineada. Estruturam-se nesse item, as diferenças principais entre os modelos 'não-atualistas', apresentados para a compartimentação das rochas do Escudo Sul-rio-grandense, e os atualistas, expressos em termos da Tectônica de Placas. As discussões sobre a origem e evolução dos modelos conhecidos como 'ensiálicos', bem como das evidências utilizadas para a proposição de um modelo desse tipo para o Escudo Sul-rio-grandense, encerram o trabalho.

Em um outro artigo, publicado nesse mesmo ncemero da Revista Brasileira de Geociências, apresentado como 'Parte II' da presente contribuição, são analisadas as evidências obtidas através da utilização de técnicas de geofísica (gravimetria e aeromagnetometria), que corroboram o modelo tectônico proposto.

GEOLOGIA E EVOLUÇ̃̃O TECTÔNICA DO CINTURÃO DOM FELICIANO Os modelos que se utilizam de um arcabouço teórico derivado da Tectônica de Placas com o propósito de explicar a origem e evolução das rochas pré-Cambrianas orogênicas do Escudo Sul-rio-grandense, parecem ser, por um lado, consensuais em relação ao entendimento de que para cada associação petrotectônica identificada é possível diagnosticar um ambiente geotectônico específico (eg. Ribeiro \& Fantinel 1978, Fragoso-César 1980, Tommasi 
\& Fernandes 1990). Por outro, apresentam variantes estruturadoras bastante distintas ( $c f$. itens 4. e 5.), decorrentes das diversas formas de relacionar tanto a natureza quanto a ordem sequencial dos eventos responsáveis pela compartimentação das respectivas associações de rochas. Em termos epistemológicos, tanto a construção quanto a escolha de uma ou outra variante deve pautar-se pela consistência e coerência metodológica em termos de uma maior ou menor testabilidade dos modelos diante dos potenciais falseadores, isto é, dos dados de campo e da forma como foram relacionados ( $c f$. Menegat \& Fernandes 1996).

Para que o leitor possa desvendar a coerência epistemológica e substantiva do modelo ora proposto para a evolução tectônica do Cinturão Dom Feliciano, apres,entar-se-á, neste item, uma síntese do arcabouço teórico-conceitual adotado. Esse modelo insere-se dentro da trajetória de um programa de pesquisa inaugurado por Ribeiro \& Fantinel (1978), que foram os primeiros a propor a construção de modelos plaquistas para o Escudo Sul-rio-grandense, revolucionando os paradigmas geológicos até então existentes ( $c f$. Menegat 1992), e seguido por Porada (1979), Fragoso-César et al. (1982, 1984, 1986), Fragoso-César \& Soliani Jr.(1984), Soliani Jr. (1986). Originalmente, as bases fundantes do modelo foram propostas por Tommasi \& Fernandes (1990) e foram sendo modificadas em função da incorporação de novos testes e dados obtidos mais recentemente. Por isso, essa concepção geotectônica ainda se mantém de fundamental importância para a pesquisa, pois não só incorpora elementos razoavelmente testados a partir dos modelos anteriores, mas também por ter sido capaz de acomodar e explicar as evidências geológicas disponíveis até o momento, respeitando os princípios de parcimônia e simplicidade ( $c f$. Menegat \& Fernandes 1996). Além disto, o modelo tem se mostrado bastante preditivo e fértil, elementos imprescindíveis para a ciência bona fide.

Segundo o modelo proposto, o Cinturão Dom Feliciano constitui-se no registro catazonal de um antigo orógeno que abrange a quase totalidade da área de afloramento do Escudo Sul-rio-grandense, o qual está representado por associações de rochas alongadas segundo uma direção NE. Esta colagem orogênica foi originada durante a convergência entre os crátons do Rio de La Plata e o do Kalahari durante o Neo-proterozóico e compreende diversas associações petrotectônicas de diferentes idades. Tais associações, reconhecidas até o presente, estão ilustradas através de um mapa esquemático (Figs. Ia \& b), acompanhado por uma sucessão de modelos simplificados (Fig. 2) que representam os diferentes estágios evolutivos responsáveis pela estruturação deste orógeno A seguir, far-se-á uma breve caracterização das associações petrotectônicas, reconhecidas do leste para o oeste.

(a) A raiz de um arco magmático de margem continental ativa - Arco Magmático I - representado por grandes volumes de rochas graníticas cálcio-alcalinas que, mostrando relações de intrusão em gnaisses kinzigíticos e mármores, foram deformadas e metamorfisadas em alto grau;

(b) Associação do Embasamento retrabalhado, representado pelos gnaisses do embasamento eoproterozóico e cobertura de rochas supracrustais da Associação da bacia marginal tectonicamente intercaladas durante a deformação tardia com transporte paralelo ao alongamento do cinturão;

(c) A raiz de um arco magmático de margem continental ativa pouco evoluído -Arco Magmático II -fragmentos de ofiolitos e sedimentos associados, representando o assoalho oceânico da bacia marginal, e

\section{(d) O Cráton Rio de La Plata.}

$\mathrm{O}$ registro da convergência de placas litosférica que resultou na colagem orogênica está organizado em associações petrotectônicas com estruturas indicativas de transporte tectônico com direção E-W, transversal ao alongamento do orógeno (deformação 'precoce'- Fig. lb). Os litodemas das associações que representam a colagem orogênica foram, posteriormente, afetados por uma deformação com transporte (NE-SW) paralelo ao alongamento do orógeno (deformação 'tardia'- Fig. 1b), acomodada por zonas de cisalhamento tangencial, nas regiões de bacia marginal com embasamento siálico, e por zonas de cisalhamento transcorrente e granitóides sintectônicos, nos arcos magmáticos ( $c f$. Fernandes et al. 1993). Esse conjunto de rochas foi, em seguida, intrudido por um grande volume de magmas graníticos pós-tectônicos (cf. Frantz \& Fernandes 1994).

Uma síntese da geologia de cada uma das associações que identificam a colagem orogênica é apresentada a seguir, utilizando-se, como exemplo, áreas representativas das mesmas, mapeadas em detalhe. As associações de rochas posteriores à estruturação da colagem não são objeto de discussão deste trabalho, embora informações acerca da sua natureza e características da deformação (tardia) que afetou as mesmas sejam apresentadas nas figuras 1 à 9 .

Associação de Arco Magmático 1 (AAM I) A Associação de Arco Magmático I (AAM I) é constituída por uma sucessão de granitóides orogênicos de diversas idades contendo roof-pendants e xenólitos de sequências de rochas supracrustais de alto grau metamórfico aflorantes na porção Leste do Escudo Sul-rio-grandense. Diversas unidades litodêmicas puderam ser reconhecidas e agrupadas em função das suas idades em relação aos episódio metamórficos e deformacionais formadores de tramas penetrativas (e.g. Hopgood 1984, Silva $\left.F^{o} 1994\right)$. Sendo cartografadas na escala de 1:25.000(e.g. UFRGS 1988,1992,1993) foram denominadas de litodemas, suites e complexos, de acordo com a nomenclatura internacionalmente adotada (cf. Hattin 1991). As sequências de rochas supracrustais são as unidades mais antigas e constituíram-se no substrato para a intrusão dos diversos granitóides.

Os granitóides orogênicos dessa associação podem ser divididos em dois complexos. Um, mais antigo, denominado de Complexo Gnáissico Arroio dos Ratos (Fernandes et al. 1990), compreendendo apenas as rochas ortometamórficas dos anteriormente denominados 'Complexo Metamórfico Várzea do Capivarita' (Frantz et al. 1984) e 'Septos do Embasamento do Batólito Pelotas' (Fragoso-César et al. 1986), é formado por granitóides, de composição granodiorítica a trondhjemítica, intrudindo as rochas supracrustais de alto grau metamórfico. Essa unidade ocupa uma área considerável na região de Encruzilhada do Sul, mas está representada apenas por xenólitos nos granitóides em locais mais próximos à região de Porto Alegre. O outro complexo, mais novo, designado de Complexo Gnáissico Piratini (Fernandes et al. 1992b), incluindo os granitóides deformados do Complexo Canguçce (Santos et al. 1989), 'gnaisses Piratini' e Suíte Pinheiro Machado (Fragoso-César et al. 1986, Philipp 1991) e 'granitóides cálcio-alcalinos da região leste' ou 'oriental' do Escudo Sul-rio-grandense (Frantz \& Nardi 1992a,b), é composto por granitóides com estruturas magmáticas preservadas, contendo xenólitos de gnaisses dioríticos porfiríticos e bandados além de gnaisses oftalmíticos, e aflora na porção mais 


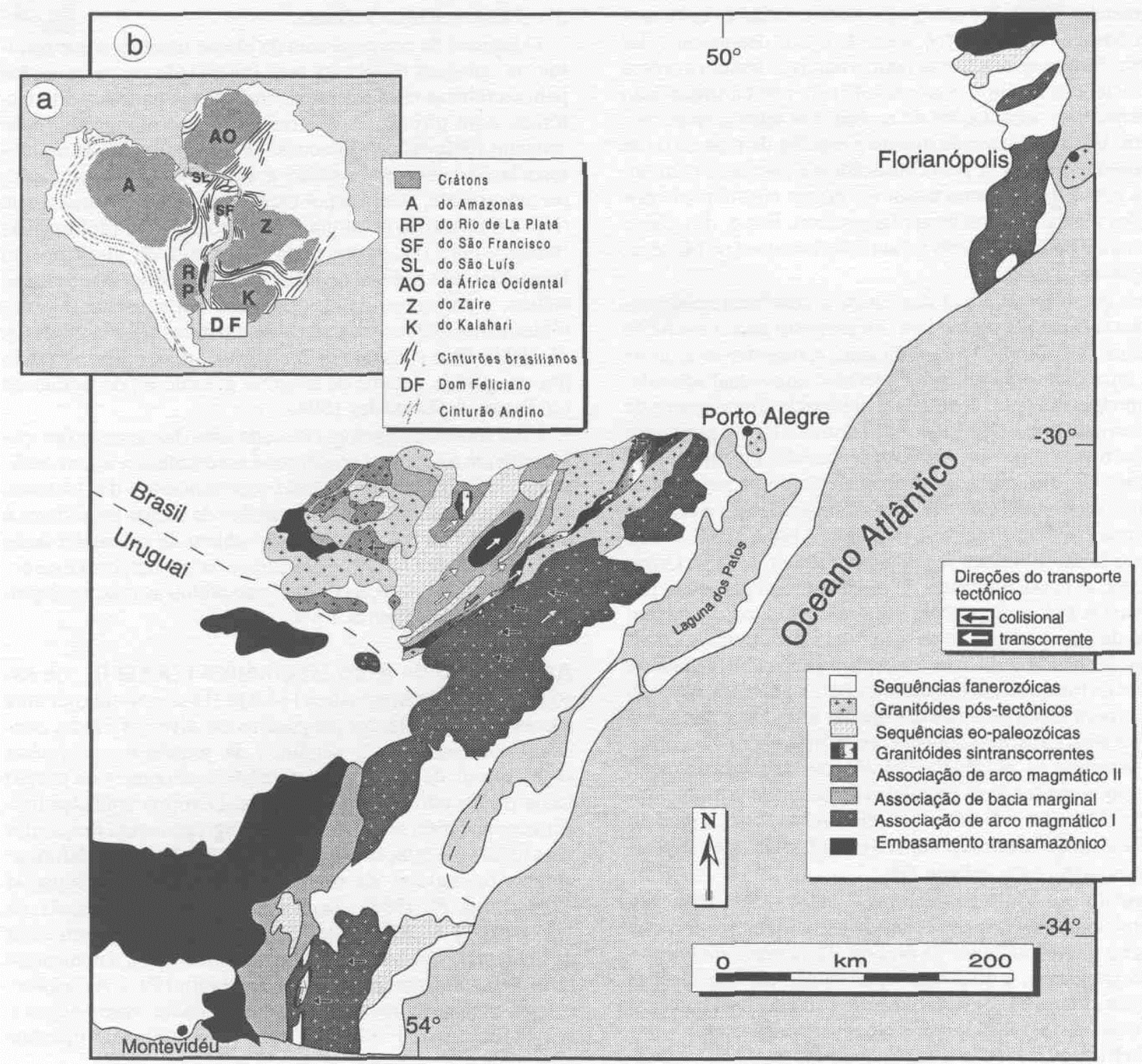

Figura 1- Unidades do Sistema Geodinâmica do Gondwana Oeste durante o Neoproterozóico (a) incluindo o mapa simplificado das associações petrotectônicas (b).

Figure - Tectonic situation of the Dom Feliciano Belt (DF) in relation to the units of the Gondwana Geodynamic System during the Neoproterozoic (a), including a simplified map of the lithotectonic assemblages of the Dom Feliciano Belt (b)

ao sul, na região de Piratini-Pinheiro Machado (SW da área ocupada pela AAM I).

\section{A UNIDADE MAIS ANTIGA DA AAM I: O COMPLE- XO GNÁISSICO ARROIO DOS RATOS Comple-} xo Gnáissico Arroio dos Ratos da AAM I, na região de Encruzilhada do Sul (Figs. 2a-c), é dominantemente representado por gnaisses tonalíticos $(\mathrm{Gl})$ mostrando um bandamento de alta temperatura cortado por apófises de granodioritos leucocráticos dobrados $(\mathrm{G} 2)$ e intrudidos por trondhjemitos grossos a pegmatóides (G3). Secundariamente, como xenóiitos (Fig. 4a), ocorre uma sequência supracrustal composta por gnaisses kinzigíticos, quartzo-feldspáticos, cálcio-silicáticos e mármores bandados, apresentando metamorfismo de alto grau e características estruturais compatíveis com os granitóides orogênicos, que a intrudiram.
As rochas supracrustais que ocorrem nesta unidade, apresentam um bandamento composicional bem desenvolvido, representando a intercalação litológica original reforçada por processos de segregação metamórfica, como é sugerido pela preservação de relictos de estratificação cruzada nos raros bancos de quartzitos intercalados com os mármores. Estruturas desenvolvidas nestas rochas durante a deformação e metamorfismo de alta temperatura e pressão baixa à média $\left(\mathrm{T}>650^{\circ} \mathrm{C}\right.$ e $4 \mathrm{~kb}<\mathrm{P}<8 \mathrm{~kb}$ ) a que foram submetidas ( $c f$. Fernandes et al. 1990, 1992a), incluem, além do bandamento composicional, lineações minerais marcadas por orientação dimensional de cristais de silimanita prismática nos metapelitos e de anfibólios nos gnaisses cálcio-silicatados. Lineações de estiramento não-penetrativas são evidenciadas por sombras de pressão de material quartzo-feldspático em granadas, representando a acumulação de fusão durante a deformação e 


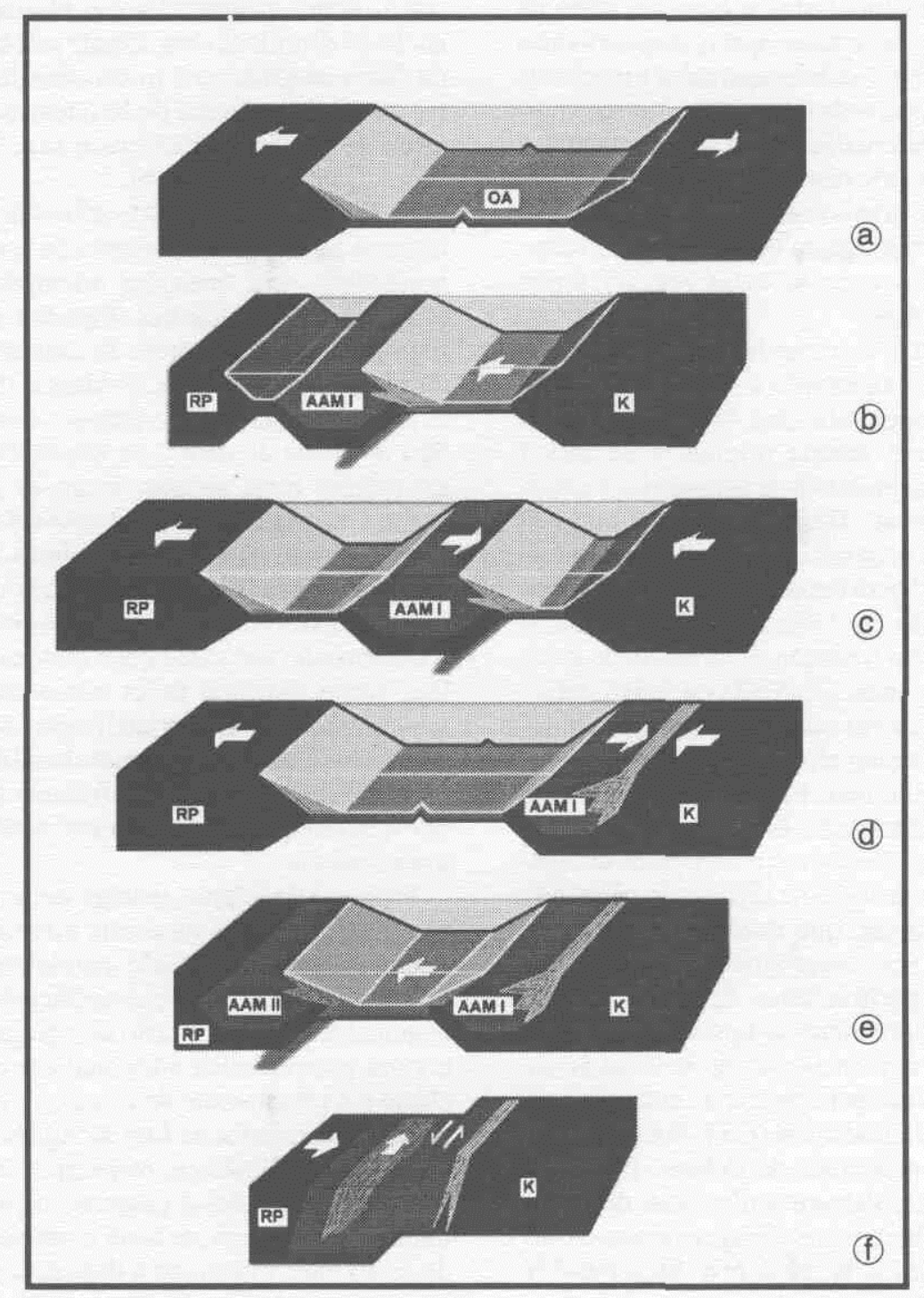

Figura 2 - Modelo evolutivo esquemático do Cinturão Dom Feliciano [DF] mostrando as associações petrotectônicas originadas pela convergência entre os crátons do Rio de La Plata [RP] e Kalahari [K]. Os seguintes estágios evolutivos são propostos para a evolução deste cinturão: (a) Deriva continental com a separação entre os Crátons do Rio de La Plata e Kalahari e formação do Oceano Adamastor. Deposição de sedimentos elásticos e carbonáticos na plataforma continental; (b) Convergência entre os Crátons do Kalahari e Rio de La Plata com o consequente fechamento do Oceano Adamastor e formação de uma margem continental ativa (Associação de Arco Magmático I-AAM I) na borda oriental do Cráton RP; (c) Formação de uma extensa bacia marginal com assoalho oceânico em função da anomalia térmica produzida pela subducção do Oceano Adamastor; (d) Colisão entre a margem continental ativa e o cráton do Kalahari, promovendo deformação intensa e metamorfismo de alta temperatura nos granitóides da AAM I. Formação de zonas de cisalhamento sub-horizontontais com transporte tectônico transversal ao orógeno; (e) Fechamento da bacia marginal com preservação de fragmentos da crosta oceânica da bacia marginal e formação de um grande volume de magmas orogênicos ao longo de uma margem continental ativa mais jovem à oeste (Arco Magmático H); (f) Colisão entre a colagem composta pelas unidades geotectônicas originadas nos estágios anteriores e o Arco Magmático II, originando zonas de cisalhamento sub-horizontontais de alta temperatura com transporte tectônico E-W. Formação de zonas de cisalhamento transcorrentes, principalmente nas AAM I e $H$, e sub-horizontontais (na região com embasamento paleoproterozóico) ambas mostrando transporte tectônico paralelo ao alongamento do Cinturão Dom Feliciano (NE-SW). Figure 2 - Schematic diagram of the sequential stages of evolution proposed for the Dom Feliciano Belt. (a) Continental drift between the Kalahari and Rio de La Plata crátons with the opening of the Adamastor Ocean. Deposition of a mature clastic and carbonate-rich shelf sedimentary sequence typical of passive margin. (b) Convergence between the Kalahari (K) and Rio de La Plata (RLP) crátons producing the closure of the Adamastor Ocean. This gave rise to an active continental margin magmatic are (Magmatic Are Assemblage I- MAA I) along the oriental boundary of the Rio de La Plata Cráton, by westward subduction of the oceanic lithosphere under the continental margin; (c) Early stages of formation of a wide ocean-floored back-arc basin caused by the thermal anomaly originated during closure of the Adamastor Ocean. (d) Collision between the active continental margin and the Kalahari Cráton (K). This produced flat-lying shear zones with E-W tectonic transport directions under high-T metamorphic conditions in the cordilleran granitoids of the MAA I; (e) Closure of the back-arc basin with emplacement of ophiolites and production of large volumes of calc-alkaline magmas along a younger active continental margin to the West (Magmatic Are Assemblage II- MAA II); (f) Collision between the collage of units formed in the previous stage (K + MAA I) with the MAA II giving rise to sub-horizontal high-T and strain zones with E-W direction of tectonic transport. Development of the transcurrent (in the MAA I \& II) and flat-lying shear zones (in áreas underlain by paleoproterozoic basement) with tectonic transport directions parallel to the length of the Dom Feliciano belt (NE-SW). 
orientação do eixo maior de litoclastos e boudins, além de charneiras de dobras. Estruturas mesoscópicas desenvolvidas durante esta deformação incluem dobras apertadas a isoclinais intrafoliares comumente observadas nas pedreiras de mármores a leste da cidade de Encruzilhada do Sul. Enquanto as lineações dessa sequência supracrustal apresentam a mesma atitude das observadas nos granitóides orogênicos (E-W e baixo caimento), as foliações mostram direções predominantemente N-S a NW em diversas exposições (cf. Fig. 3c), sendo controladas pelas dobras tardias.

A história deformacional e metamórfica dos granitóides orogênicos é bastante complexa devido a presença de zonas de deformação de alta temperatura (Fig.4b) e abundantes indicadores cinemáticos, cuja atitude original é de difícil identificação em função da complexidade geométrica e exposição insuficiente das mesmas. Desse modo, foi possível reconstituir apenas a atitude original das zonas de alta deformação mais novas e de mais baixa temperatura (fácies anfibolito a xisto verde) observadas no (G3). Essas, são marcadas por um bandamento milonítico (redução de tamanho de grão) irregular que contorna litoclastos $(\mathrm{X}>\mathrm{Y}>\mathrm{Z})$ de baixa deformação. As feições não-pervasivas mais comuns incluem dobras isoclinais e intrafoliares com charneiras espessadas que afetam um bandamento milonítico. Feições lineares observadas na trama de alta deformação incluem lineações de estiramento de enclaves, fitas de quartzo e feldspatos alongados, além da orientação dimensional de cristais de silimanita e charneiras de dobras disruptas, que mostram atitude subhorizontal e direção E-W (cf. estereogramas da Fig. 3c). Bandas de cisalhamento e porfíroclastos de feldspato com caudas de recristalização assimétricas do tipo sigma indicam a movimentação do topo da sequência para oeste (Figs.4c-d). Esta trama composta é truncada pelas zonas de cisalhamento transcorrente e granitóides sintectônicos (GST-Fig. 3c) e afetada por quatro conjuntos principais de dobras. Estas são abertas, normais e horizontais, planas e acilíndricas, de escala macro- e mesoscópica, com direções de clivagens plano-axiais (espaçada e/ou de crenulação) E-W, N-S, NW-SE e NE-SW (Fernandes et al. 1990).

Apesar das mudanças químicas sofridas durante o metamorfismo e deformação, estudos geoquímicos preliminares (Fernandes et al. 1992b) permitiram caracterizar os granitóides da porção setentrional da AAMI como magmas cálcioalcalinos médio à alto-K.

A idade de $723 \pm 13 \mathrm{Ma}$ (Tab. Ia) obtida para o granitóide trondhjemítico mais novo (G3) da suíte cálcio-alcalina (Tommasi 1991) é atribuída ao metamorfísmo de fácies anfibolito superior registrado nessas rochas, como indicado pelas paragêneses e microestruturas desenvolvidas.

\section{A UNIDADE MAIS NOVA DA AAM I: O COMPLEXO} GNÁISSICO PIRATINI O Complexo Gnáissico Piratini, composto predominantemente por granitóides orogênicos ('gnaisses migmatíticos') e, secundariamente, por xenólitos de gnaisses bandados e de gnaisses oftalmíticos (Figs. 5 \& 6a-c). Encontram-se, também, em menor quantidade, xenólitos de rochas supracrustais, similarmente aos descritos na unidade mais antiga.

Os granitóides orogênicos apresentam estruturas magmáticas mais bem preservadas do que as da unidade mais antiga, apesar das evidências de fusão parcial nos gnaisses quartzo feldspáticos (cf. Tommasi et al. 1992). O fluxo magmático planar é marcado pela alternância de bandas quartzo feldspáti- cas e outras enriquecidas em biotitas, além de schlieren de enclaves dioríticos com atitude sub-horizontal. Uma lineação de fluxo magmático é materializada pela orientação dimensional de megacristais de K-feldspato, bem como pela orientação de enclaves dioríticos e xenólitos tabulares de rochas supracrustais (Figs. $6 \mathrm{a}-\mathrm{b}$ ).

A deformação no estado sólido desses granitóides é caracterizada pelo desenvolvimento de zonas de cisalhamento subhorizontais com lineações orientadas NW-SE, retirados os efeitos das dobras tardias (Figs.5c). Essa trama é claramente reproduzida pelos padrões de anisotropia de susceptibilidade magnética (cf. Costa \& Caldasso 1994). A trama deformacional apresenta características variáveis em função de cada tipo de rocha afetada e da intensidade da deformação. Nos granitóides mais antigos, como os gnaisses dioríticos, essa trama é marcada por megacristais de plagioclásio zonados e com formas assimétricas irregulares. Os gnaisses oftalmíticos mostram bandas de cisalhamento (Fig.6c) e caudas de recristalização assimétricas marcando a direção de extensão durante a deformação sob condições metamórficas da fácies anfibolito, como indicado pelas microestruturas em feldspatos e reações produzindo a cristalização de biotitas castanho-avermelhadas. A orientação dimensional de cristais de hornblenda, frequentemente mostrando fraturas de extensão preenchidas por quartzo ou substituição por biotita, é a lineação mineral mais comum.

Extinção ondulante, macias mecânicas e contatos suturados são feições comuns na escala microscópica, embora a trama cristalografica tenha sido parcialmente obliterada por um episódio de recristalização estática posterior. Esse evento foi responsável pela formação de agregados policristalinos com textura granoblástica poligonal em porfiroclastos de plagioclásio e o crescimento de cristais de quartzo por migração de contatos no interior de fitas alongadas nos enclaves dioríticos e gnaisses oftalmíticos, respectivamente ( $c f$. Tommasi et al. 1992). Os indicadores cinemáticos mais comuns nesses granitóides orogênicos incluem o entelhamento de megacristais de feldspatos, marcando a direção e o sentido do fluxo magmático, e bandas de cisalhamento e caudas de recristalização assimétricas, indicando o transporte tectônico de topo-paraNW. Além disto, as tramas registradas nesses granitóides orogênicos são truncadas pelas zonas de cisalhamento (Figs.6 d-e) do Sistema de Transcorrência Dorsal de Canguçce e afetadas pelos mesmos conjuntos de dobras normais tardias registradas nas rochas da unidade mais nova dessa associação (Fernandes et al. 1993, Tommasi et al. 1994b).

Os dados geoquímicos do Complexo Gnáissico Piratini permitem caracterizá-lo, preliminarmente, como cálcio-alcalino orogênico baixo- a médio-K (Fragoso-César et al. 1986, Figueiredo et al. 1990, Frantz \& Nardi 1992a,b).

As idades de 616 e 572 Ma obtidas recentemente através do método $\mathrm{Pb} / \mathrm{Pb}$ em zircão (Chemale Jr. et al. 1995a) são inconsistentes com as relações de campo e claramente discordantes das idades $\mathrm{Rb} / \mathrm{Sr}$ anteriormente obtidas para estas rochas ( $c f$. Tab. Ia). Em função da localização das amostras analisadas, possivelmente refletem as idades da fusão crustal responsável pela geração e posicionamento dos granitóides sintectônicos às zonas de cisalhamento transcorrentes ( $c f$. abaixo e Koester et al. 1995, 1996).

Associações do Embasamento Retrabalhado e da Bacia Marginal A associação petrotectônica da porção central do Escudo Sul-rio-grandense é caracterizada por 


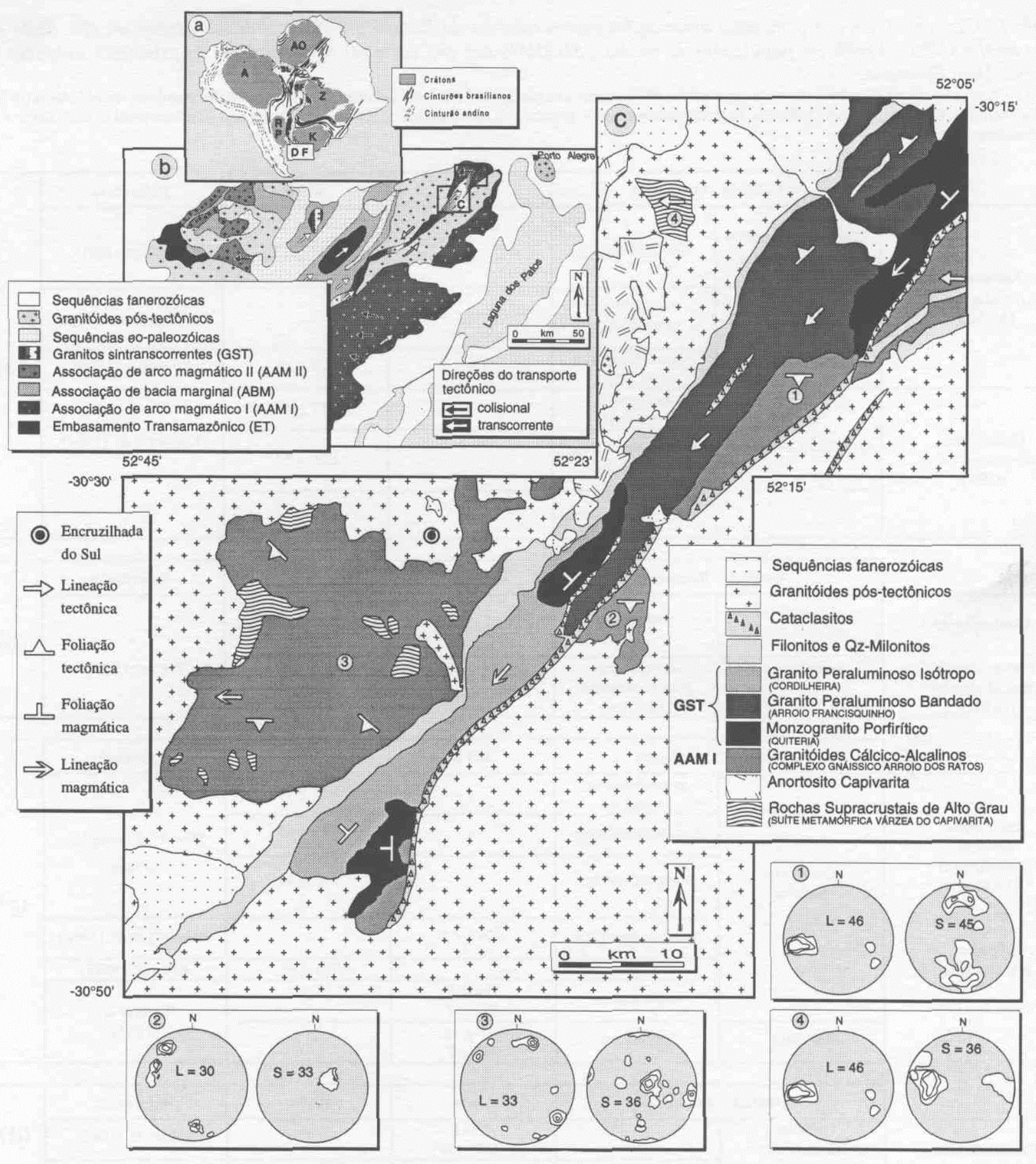

Figura 3 - Unidades do Sistema Geodinâmica do Gonduana Oeste durante o Neoproterozóico (a) incluindo o mapa simplificado das associações petrotectônicas (b). Mapa geológico da região de Encruzilhada do Sul (c), onde afloram os granitóides cálcio-alcalinos orogênicos mais antigos (Complexo Gnáissico Arroio dos Ratos-cgAR) e suas rochas encaixantes (Suite Metamórfica Várzea do Capivarita-smVC) apresentando a orientação dos elementos da trama (Estéreogramas l a 4). A Sutura de Porto Alegre é marcada pela zona cataclástica NE que inflete para E na sua porção setentrional, sendo marcada por granitóides pós-tectônicos (SE do mapa) que aproveitaram essa descontinuidade para o seu posicionamento. Note-se que a Zona de Cisalhamento Dorsal de Canguçu é obliqua à sutura (cf. também a Fig.3, Parte II desse artigo), encaixando-se nesta altima na latitude da cidade de Encruzilhada do Sul.

Figure 3 - Tectonic situation of the Dom Feliciano Belt (DF) in relation to the units of the Gondwana Geodynamic System during the Neoproterozoic (a), including a simplified map of the lithotectonic assemblages of the Dom Feliciano Belt (b). Inset shows location of figure c. Geological map of the Encruzilhada do Sul region (c) where the old calc-alkaline granitoids of the Magmatic Are Assemblage I (AAM I, complexo gnáissico Arroio dos Ratos-cgAR) and their host rocks represented by xenoliths of high-grade supracrustal rocks (suite metamórfica Várzea do Capivarita-smVC) crop out. Structures of the main fabric of these rocks are presented in the stereonets ( 1 to 4 ). In this map, the position of the Porto Alegre Suture Zone is marked by a zone of cataclasite with NE to E-W trenas (along its northern segment)along the boundary of a post-tectonic granitoid (SE of the map), that used this discontinuity for its emplacement. Note the obliquity between the Dorsal de Canguçoe Transcurrent Shear Zone with its syntectonic granites ('GST' in legend) and the Porto Alegre Suture Zone (cf. also Fig.3, Part II of this paper). The former merges towards the latter around the latitude of the town of Encruzilhada do Sul. 
Tabela l - Geocronologia das principais associações petrotectônicas do Escudo Sul-rio-grandense. Idades em Ma. Rb/Sr em rocha total e U/Pb e Pb/Pb em populações de zircão e SHRIMP. (a), (b), (c) e (d) correspondem às principais unidades do Cinturão Dom Feliciano.

Table 1 - Geochronological data from the main units of the lithotextonic assemblages of the Dom Feliciano Belt in the Sul-rio-grandense Shield. Ages (in Ma) from the literature, $\mathrm{Rb} / \mathrm{Sr}$ whole-rock, $\mathrm{U} / \mathrm{Pb}$ and $\mathrm{Pb} / \mathrm{Pb}$ in selected zircon populations and SHRIMP methods. (a), (b), (c), and (d) correspond to main units of the Dom Feliciano Belt.

\begin{tabular}{|c|c|c|c|c|c|c|}
\hline & Unidade & litodêmica & $\mathrm{Pb} / \mathrm{Pb}$ & $\mathrm{Rb} / \mathrm{Sr}$ & Referência & \multirow{7}{*}{ (a) } \\
\hline \multirow{3}{*}{$\begin{array}{c}\text { Associação } \\
\text { de Arco Magmático I } \\
\text { (AAM-I) }\end{array}$} & $\begin{array}{l}\text { Complexo Gnássico } \\
\text { Arroio dos Ratos }\end{array}$ & G3-trondhjemito & . & $723 \pm 13$ & Tommasi (1991) & \\
\hline & \multirow{2}{*}{$\begin{array}{c}\text { Complexo Gnấssico } \\
\text { Piratini }\end{array}$} & $\begin{array}{l}\text { tonalitose } \\
\text { granodioritos }\end{array}$ & $\begin{array}{c}572 \\
598 \\
616 \pm 13 \\
\end{array}$ & - & Chemale et al. (1995a) & \\
\hline & & $\begin{array}{l}\text { granitóides da fase } \\
\text { precoce }\end{array}$ & - & $827 \pm 25$ & Soliani Jr. (1986) & \\
\hline \multirow{3}{*}{$\begin{array}{c}\text { Granitóides } \\
\text { Sintranscorrentes } \\
\text { (GST) }\end{array}$} & Suíte & $\begin{array}{l}\text { metagranito } \\
\text { Cordilheira }\end{array}$ & - & $617 \pm 48$ & \multirow{3}{*}{ Koester et al. (1994) } & \\
\hline & Granítica Cordilheira & $\begin{array}{l}\text { metagranito Arroio } \\
\text { Francisquinho }\end{array}$ & - & $628 \pm 22$ & & \\
\hline & & metagranito Quitéria & - & $672 \pm 22$ & & \\
\hline
\end{tabular}

\begin{tabular}{|c|c|c|c|c|c|c|}
\hline & Unidade & litodêmica & $\mathrm{U} / \mathrm{Pb}$ & $\mathrm{Rb} / \mathrm{Sr}$ & Referência & \multirow{3}{*}{ (b) } \\
\hline Associação do & $\begin{array}{c}\text { Granitóides } \\
\text { milonitizados }\end{array}$ & sienogranito & - & $1.833 \pm 56$ & \multirow[b]{2}{*}{ Porcher (1992) } & \\
\hline $\begin{array}{c}\text { Embasamento } \\
\text { Retrabalhado } \\
\text { (AER) }\end{array}$ & Gnaisses Encantadas & $\begin{array}{c}\text { ortognaisses } \\
\text { granodioríticosà } \\
\text { tonalíticos }\end{array}$ & - & $2.083 \pm 45$ & & \\
\hline
\end{tabular}

\begin{tabular}{|c|c|c|c|c|c|c|}
\hline & Unidade & litodêmica & $\mathbf{U} / \mathbf{P b}$ & $\mathrm{Rb} / \mathrm{Sr}$ & Referência & \\
\hline \multirow{3}{*}{$\begin{array}{c}\text { Associação } \\
\text { de Arco } \\
\text { Magmático II } \\
\text { (AAM-II) }\end{array}$} & \multirow{6}{*}{$\begin{array}{l}\text { Complexo } \\
\text { Cambaí }\end{array}$} & $\begin{array}{c}\text { granodioritose } \\
\text { adamelitos }\end{array}$ & - & $643 \pm 28$ & \multirow{3}{*}{$\begin{array}{c}\text { Silva F \& Soliani Jr. } \\
\text { (1987) }\end{array}$} & \\
\hline & & gnaisses tonalíticos & . & $673 \pm 65$ & & \\
\hline & & gnaisses dioríticos & - & $703 \pm 41$ & & (c) \\
\hline \multirow{4}{*}{$\begin{array}{c}\mathrm{e} \\
\text { ofiolitos } \\
\text { relacionados }\end{array}$} & & gnaisses dioríticos & $704 \pm 13$ & - & Babinsky et al. (1996) & \\
\hline & & tonalitos & - & $701 \pm 61$ & Kraemer (1995) & \\
\hline & & metatonalitos & $\begin{array}{l}704 \pm 8 \\
722 \pm 9\end{array}$ & - & \multirow{2}{*}{$\begin{array}{l}\text { Leite } \text { et al. } \\
\text { (1995) }\end{array}$} & \\
\hline & Ofiolitos & anfibolitos & $\begin{array}{l}711 \pm 12 \\
737 \pm 7\end{array}$ & - & & \\
\hline
\end{tabular}

\begin{tabular}{c|c|c|c|c|c|}
\cline { 2 - 5 } & \multicolumn{2}{|c|}{ Unidade litodêmica } & U/Pb & Rb/Sr & Referência \\
\hline \multirow{2}{*}{$\begin{array}{c}\text { Cráton do Rio } \\
\text { de La Plata } \\
(\text { CRP) }\end{array}$} & $\begin{array}{c}\text { Complexo } \\
\text { Granulítico } \\
\text { Santa Maria Chico }\end{array}$ & & $\begin{array}{c}2.541 \\
(+167-189)\end{array}$ & Soliani Jr. (1986) \\
\cline { 3 - 6 }$(\mathbf{d})$
\end{tabular}

um padrão estrutural definido pela intercalação tectônica de urna associação de rochas supracrustais com gnaisses do embasamento paleoproterozóico das porções internas do cinturão segundo uma direção de transporte NE-SW (Figs. 7a-d). O embasamento é representado por ortognaisses granodioríticos a tonalíticos, bandados e anfibolitos, bastante homogéneos em termos de composição mineral e apresentando razões ${ }^{87} \mathrm{Sr} /{ }^{86} \mathrm{Sr}$ baixas $(0.702)$, fornecendo idades em torno de $2.200 \mathrm{Ma}(\mathrm{Rb} / \mathrm{Sr}$ - cf. Tab. Ib). Intrusivos nos gnaisses, foram reconhecidos dois granitos de composição monzo- e sienogranítica. O oeltimo, emite apófises facilmente reconhe- cidos nos gnaisses bandados em função da sua composição ser mais contrastante com as bandas dos gnaisses. Datações $(\mathrm{Rb}-$ $\mathrm{Sr})$ preliminares desses granitóides milonitizados forneceram idades em torno de 1.900 Ma (Porcher \& Fernandes 1992).

As rochas supracrustais, identificadas por metapelitos, quartzitos, mármores e metavulcânicas ácidas a intermediárias e de baixo grau metamórfico, consideradas como representativas da sequência ('mioclinal') de Bacia Marginal ( $c f$. Jost \& Bitencourt 1980, Jost 1981, Fragoso-César et al. 1982, 1984, Tommasi \& Fernandes 1990), afloram em uma faixa alongada NE-SW que se estende até a fronteira com o Uruguai. 

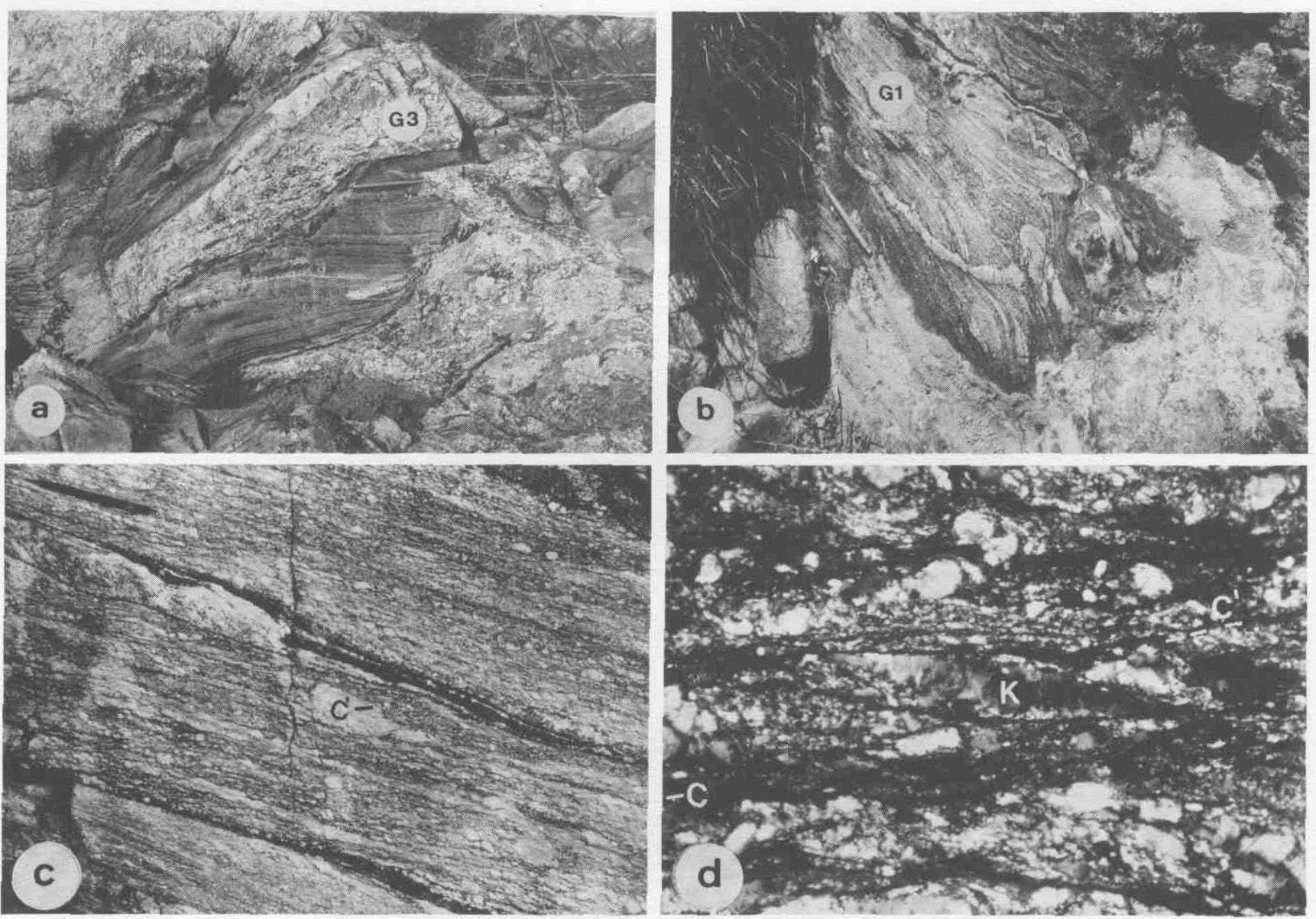

Figura 4 - Estruturas típicas dos litodemas mais antigos da Associação de Arco Magmático I na região de Encruzilhada do Sul mostram o granitóide tardio do cgAR (G3) com xenólito de kinzigito bandado da smVC (a). Bandamento milonítico de alta-Tdo granitóide cálcico-alcalino mais antigo do cgAR (Gl), cortado por veio (dobrado) de um dos granitóides mais novos (G2) do mesmo complexo (b). Detalhe da zona de cisalhamento sub-horizontal tardi-colisional registrada no granitóide mais novo do cgAR (G3), mostrando as superficies principais de cisalhamento (paralelas à caneta) truncadas por bandas de cisalhamento-C' (c). Detalhe da figura anterior ao microscópio. $C^{\prime}$ corresponde à superfície principal de cisalhamento e $C$ às bandas de cisalhamento, enquanto $\mathrm{K}$ marca um porfiroclasto alongado de feldspato potássico (d). As dimensões das escalas são de $15 \mathrm{~cm}$ para as canetas enquanto afotomicrografia mostra aumento de 120 vezes.

Figure 4 - Typical structures of the older lithodemes of this region with the youngest of the calc-alkaline granitois of the $\operatorname{cgAR}$ (G3) showing a xenolith of banded kinzigite of the smVC (a). High-T mylonitic banding of the oldest granitoid of cgAR (G1) cut by vein (folded) of one of the younger granitoid (G2) of this complex (b). Detail of the late-collisional sub-horizontal shear zone developed upon the youngest granite of the cgAR (G3) showing the main shear surfaces (C-planes, parallel to pen) displaced along oblique shear bands-C (c). View of the same structure under the microscope. C' corresponds to the main shear planes and $\mathrm{C}$ to the shear bands, while ' $\mathrm{K}$ ' marks and elongated K-feldspar crystalloclast (d). Pen for scale is $15 \mathrm{~cm}$ long and photomicrograph shows $120 \mathrm{x}$ enlargement.

Em contraste com as sequências de rochas supracrustais que afloram na porção ocidental do Cinturão Dom Feliciano $(c f$. item 2.3), onde intercalações de rochas ultramáficas são bastante comuns, essa sequência é distintamente mais matura e contém pequenas lentes de rochas ultramáficas com cromita podiforme, de significado ainda obscuro, na sua porção setentrional de afloramento (Folha Cerro da Árvore - $c f$. Marques 1996).

Os eventos deformacionais que afetaram essa associação petrotectônica incluem a deformação eoproterozóica de alto grau (anfibolito a granulito-Jost 1981), que originou o bandamento nos gnaisses, e a deformação tangencial com transporte tectônico NE-SW, responsável pelo desenvolvimento das tramas de fácies anfibolito a xisto verde, registradas principalmente nas rochas supracrustais da cobertura e nos granitóides milonitizados (Porcher \& Fernandes 1990). As tramas nas rochas do embasamento e da cobertura desenvolvidas durante essa deformação foram afetadas por dobras abertas, normais a inclinadas, com charneiras com duplo caimento (NE-SW e NW-SE). As dobras NE-SW de escala regional incluem a antiforme periclinal de Santana ('Domo de Santana' sensu Jost \& Bitencourt 1980) e as antiformes Serra dos Pedrosas e Capané. Além disso, falhas rcepteis mais jovens, como as que limitam os sedimentos das bacias transcorrentes, seccionam essas dobras e mostram movimentos direcionais e inversos.

A deformação tangencial é caracterizada, nos gnaisses, por estruturas mesoscópicas que incluem dois conjuntos de dobras cilíndricas apertadas a isoclinais com charneiras NW e NE em porções de baixa e alta deformação, respectivamente. Dobras em bainha são comuns em zonas de intensidade de deformação intermediária (Fig. 8a). Estruturas lineares estão particularmente bem desenvolvidas incluindo lineações de estiramento em cristais de feldspatos e quartzo, além de lineações minerais marcadas por orientação dimensional de cristais de anfibólio. 


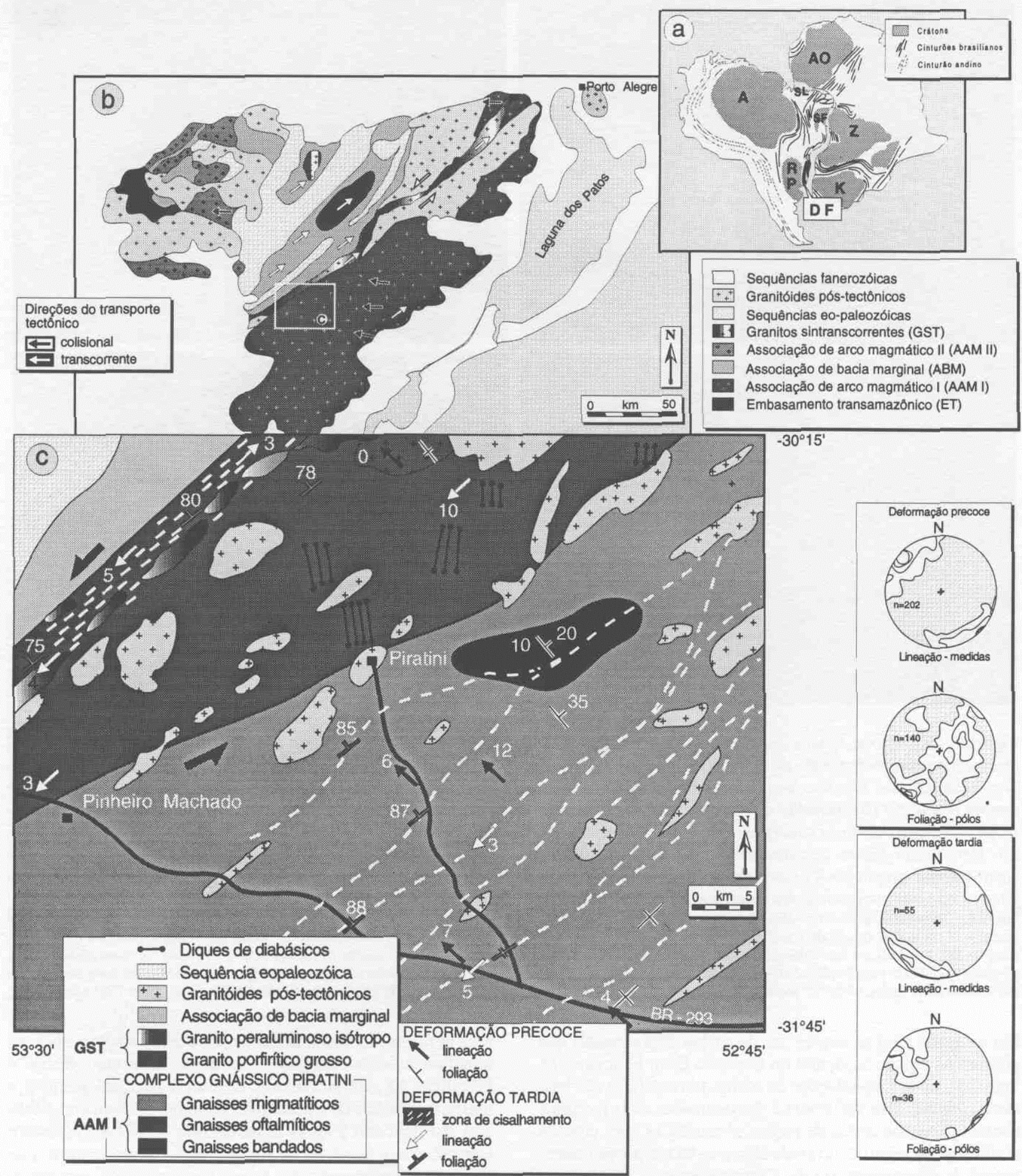

Figura 5 - Unidades do Sistema Geodinâmica do Gondwana Oeste durante o Neoproterozóico (a) incluindo o mapa simplificado das associações petrotectônicas (b). Mapa geológico da região de Piratini -Pinheiro Machado (c), onde afloram os granitóides cálcico-alcalinos orogênicos mais jovens da Associação de Arco Magmático I (Complexo Gnáissico Piratini). Estereogramas mostram as atitudes das estruturas tectônicas da deformação colisional e da transcorrência (Deformação Tardia), esta celtima particularmente desenvolvida no $\mathrm{NW}$ da região.

Figure 5 - Tectonic situation of the Dom Feliciano Belt (DF) in relation to the units of the Western Gondwana Geodynamic System during the Neoproterozoic (a), including a simplified map of the lithotectonic assemblages of the Dom Feliciano Belt (b). Geological map of Piratini -Pinheiro Machado region (c) where the younger calc-alkaline granitoids of the Magmatic Are Assemblage I crop out (complexo gnáissico Piratini). Stereonet show the altitude of the main tectonic structures developed during the collision and the transcurrent episodes. The latter are particularly well-developed in the NW of the region, where the syntranscurrent granites (GST) crop out. 

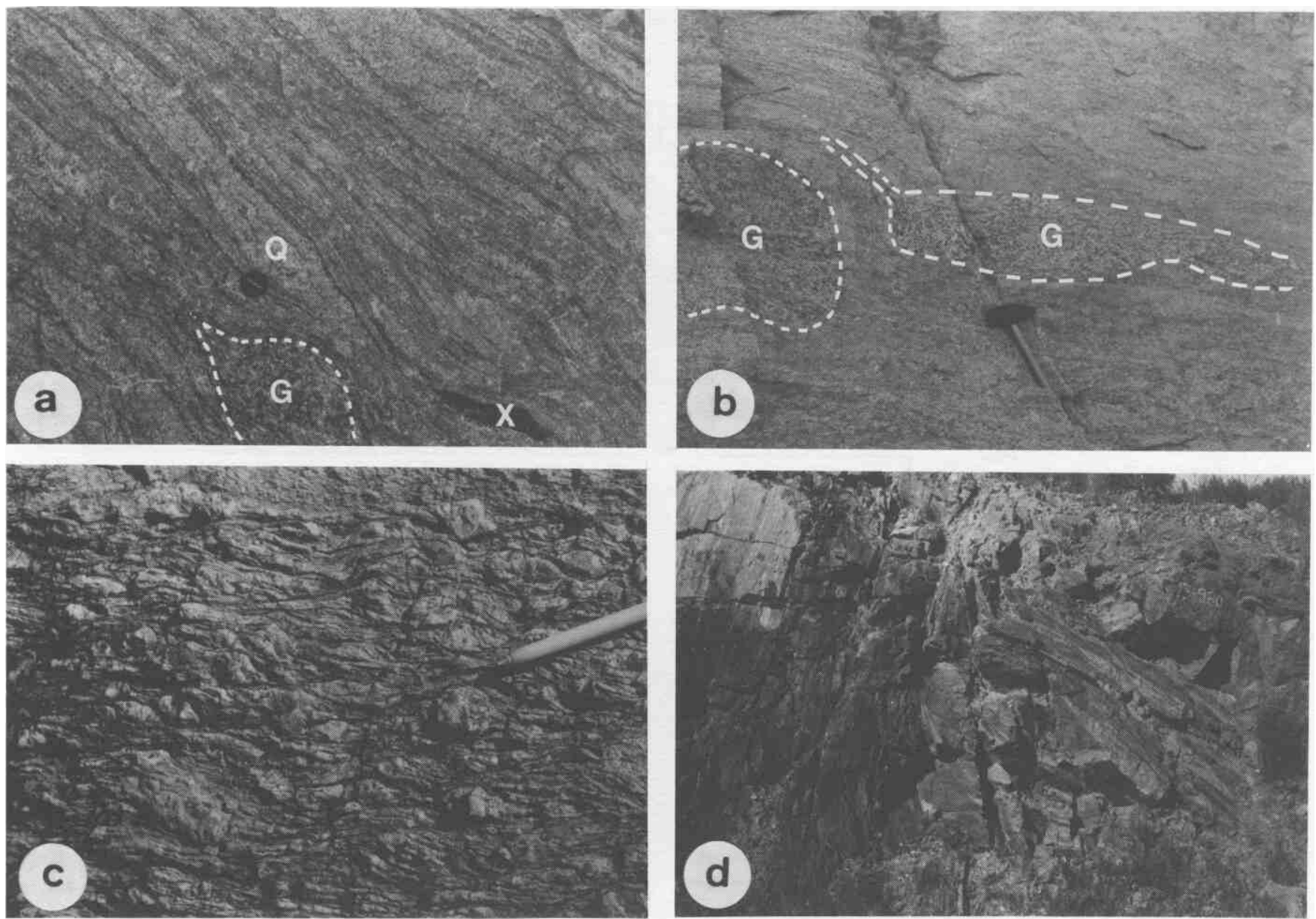

Figura 6 - Principais estruturas registradas nas rochas do Complexo Gnáissico Piratini incluem o bandamento composicional (a) marcado por bandas máficas e descontínuas circundando lentes quartzo feldspáticas (Q), xenólitos de rochas supracrustais $(X)$ e enclaves de composição granodiorítica (G) nas porções graníticas. A assimetria (b) dos enclaves granodioríticos $(G)$ e o truncamento da foliação (acima do xenólito na Fig.a) indica o movimento do topo da sequência para NW durante o fluxo magmático. Bandas de cisalhamento (c) nos gnaisses oftalmíticos (paralelas à caneta), um dos litodemas mais antigos dessa associação indicam igualmente transporte tectônico para $N W$ durante a deformação de alta-T no estado sólido. As estruturas relacionadas à deformação por transcorrência (Deformação Tardia) que afetou estas rochas são caracterizadas por zonas de cisalhamento discretas subverticais nas imediações das quais a foliação sub-horizontontal de alta-T e mais antiga é rotada

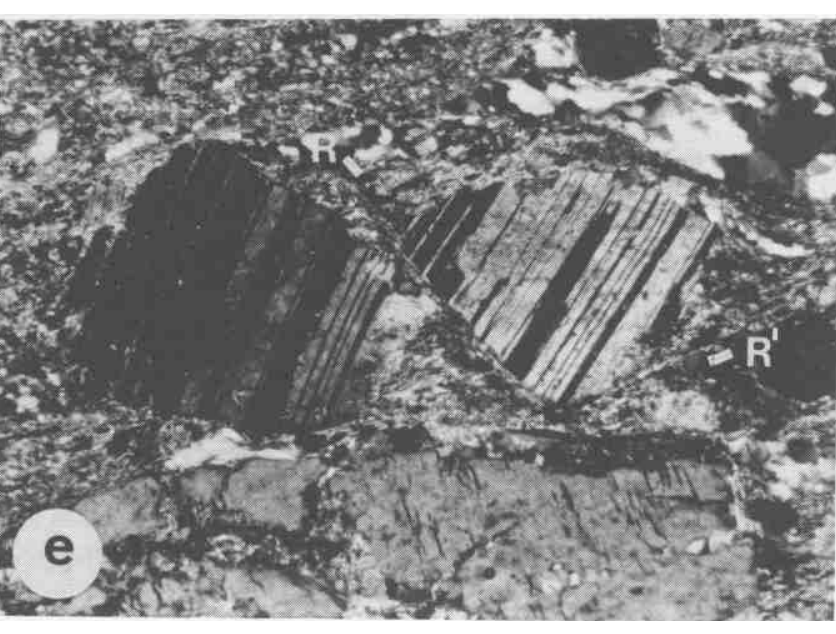
para a posição sub-vertical (d). Microestruturas de baixa-T são representadas por fraturas sintéticas $(R)$ e antitéticas $\left(R^{\prime}\right)$ afetando porfiroclastos de feldspato (e) indicando movimento do topo para a direita (dextral). As dimensões das escalas são de $45 \mathrm{~cm}$ para o cabo da marreta, $10 \mathrm{~cm}$ para a caneta e $5 \mathrm{~cm}$ para a capa da lente, além de, um aumento de 120 vezes para a fotomicrografia.

Figure 6 - Main structures registered in the rocks of the Piratini Gnaissic Complex presenting the compositional banding (a) marked by discontinuous mafic bands surrounding quartzofeldspathic lenses $(\mathrm{Q})$, xenoliths of supracrustal rocks $(\mathrm{X})$ and granodioritic enclaves $(\mathrm{G})$ within a granitic mass. The asymmetry $(\mathbf{b})$ of granodioritic enclaves $(\mathrm{G})$ and the truncation of the foliation (above the xenolith in Fig.a) indicates a top-to-NW sense of shear during magmatic flow. Shear bands (c) in the pophyroclastic gneisses (parallel to pen), one of the oldest lithodemes of this sequence, indicates tectonic transport towards NW during the high-T solid-state deformation. With the exception the main transcurrent shear zone, where the syntectonic granitoids crop out (cf. Fig.5), most of the structures related to the transcurrent deformation are decametric-thick discrete shear zones in the proximity of which the older and sub-horizontal foliation is rotated towards a sub-vertical position (d). Low-T microstructures are represented by syntectic $(\mathrm{R})$ and antithectic fractures $\left(\mathrm{R}^{\prime}\right)$ affecting feldspar crystalloclasts (e) that indicate a dextral shear sense for the discrete shear zones (top-to-right in the picture). Scales include a $45 \mathrm{~cm}$ long hammer, a lens cap with $5 \mathrm{~cm}$ in diameter and a $120 \mathrm{x}$ enlarged photomicrograph. 


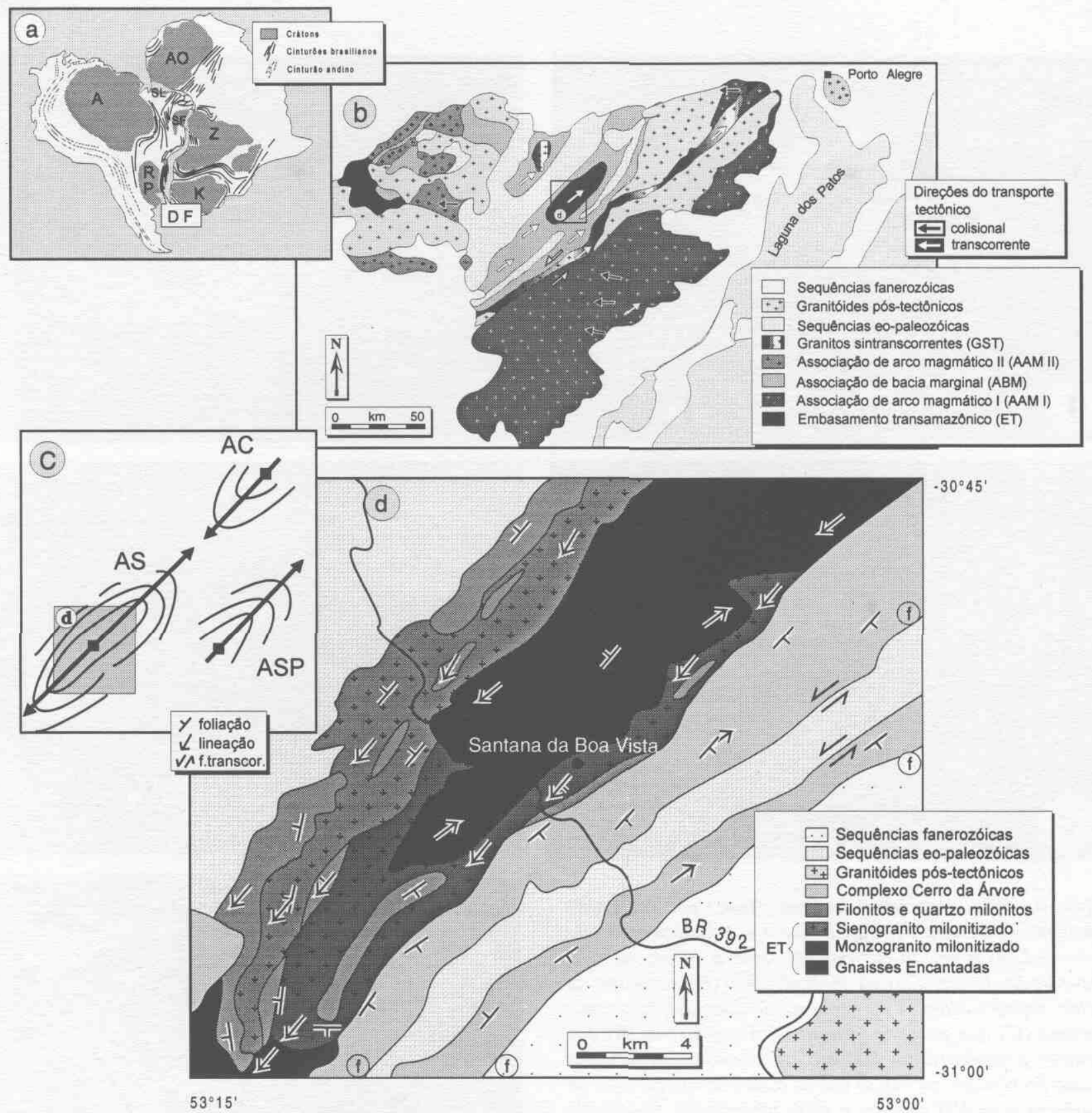

Figura 7 - Unidades do Sistema Geodinâmica do Gondwana Oeste durante o Neoproterozóico (a) incluindo o mapa simplificado das associações petrotectônicas (b). Esquema simplificado da estruturação da região - antiformes de Santana (AS), Capané (AC) e Serra dos Pedrosas (SP) -(c) e o mapa geológico da região de Santana da Boa Vista (d), mostrando a porção sul e o ncecleo de uma antiforme periclinal onde afloram os gnaisses e granito deformados (ET) do embasamento paleoproterozóico. Figure 7 - Tectonic situation of the Dom Feliciano Belt (DF) in relation to the units of the Gondwana Geodynamic System during the Neoproterozoic (a), including a simplified map of the lithotectonic assemblages of the Dom Feliciano Belt (b). Inset shows location of figures $\mathrm{c}$ and d. Outline of the major folds of the region (c) representing the antiforms of Santana (AS), Capané (AC) and Serra dos Pedrosas (SP). Geological map of Santana da Boa Vista region (d) showing the south-western segment and part of the core of a periclinal antiform where paleoproterozoic basement gneisses and granites (ET) crop out.

A estrutura mais comum nos granitóides milonitizados, gerados nesta fase deformacional, é a foliação milonítica e a lineação de estiramento marcadas por muscovita, biotita além de porfiroclastos de quartzo e feldspatos alongados (Figs.8 b-d). Esses oeltimos, são frequentemente assimétricos, indicando o movimento do topo da sequência para NE, se observados nas seções paralelas ao plano XZ dos tectonitos.

Nas rochas supracrustais, a deformação tangencial é identificada por uma xistosidade regional onde podem ser reco- nhecidos relictos de uma foliação anterior, geralmente preservados sob a forma de charneiras de dobras intrafoliais sem raiz. Boudins de quartzo e lineações minerais marcadas por orientação dimensional de cristais de anfibólios são as estruturas mais comuns nessa sequência. Com exceção das rochas metavulcânicas ácidas, onde feições de recristalização dinâmica típicas de rochas miloníticas são bastante comuns, as texturas predominantes nesta sequência de rochas são de recristalização metamórfica. Nas rochas metavulcânicas é 

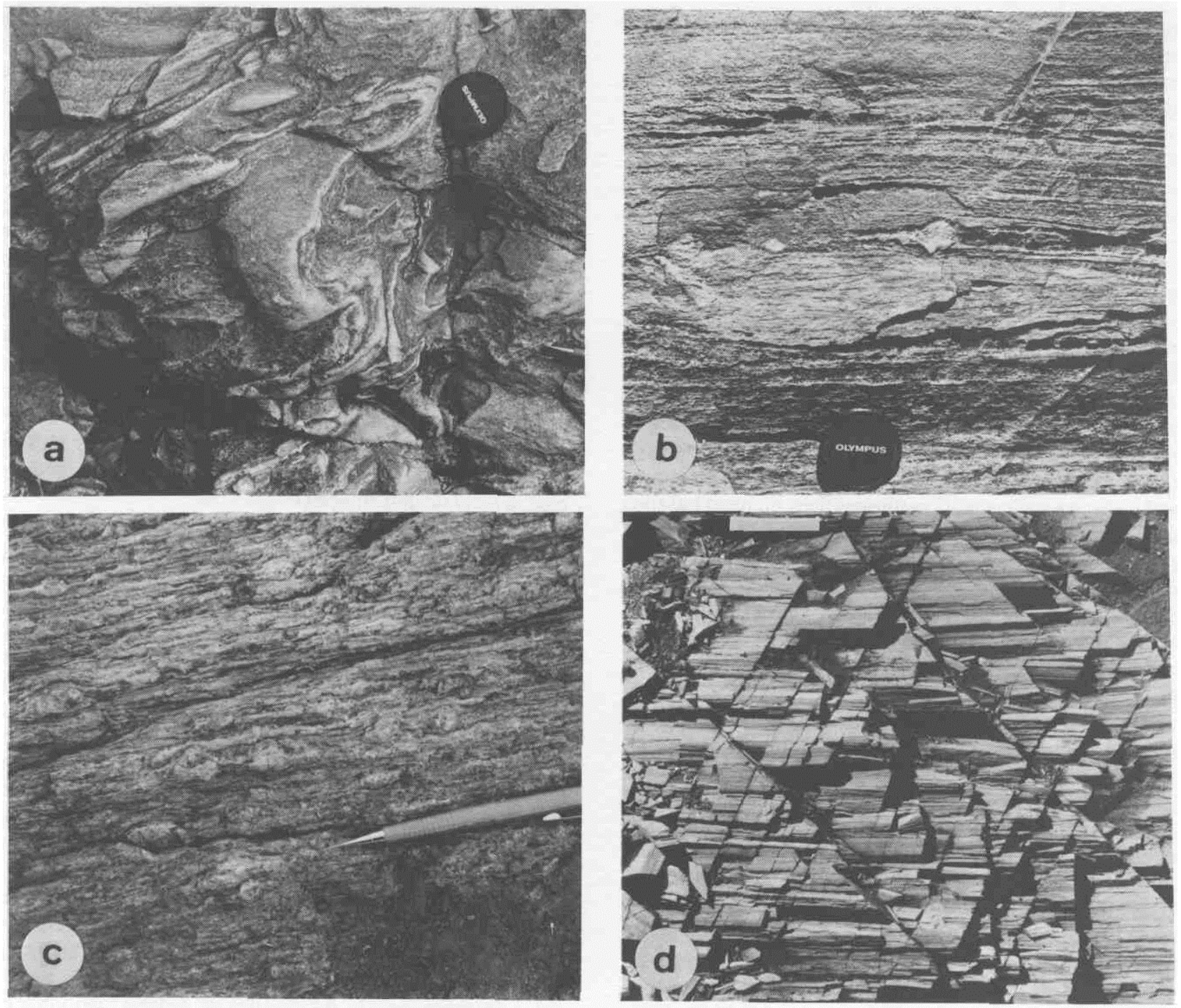

Figura 8 - As rochas do embasamento na região de Santana da Boa Vista apresentam feições mesoscópicas como dobras em bainha nos gnaisses (a), que são totalmente transpostas nas zonas de alta intensidade de deformação (b). Feições semelhantes são observadas nos monzogranitos porfiriticos (c) onde a deformação extrema de porfiroclastos de feldspatos, acompanhada de segregação de quartzo, mostrando intensa deformação, originam quartzo-milonitos (d). As dimensões das escalas são de $10 \mathrm{~cm}$ para a caneta e de $5 \mathrm{~cm}$ para a capa da lente.

Figure 8 - Mesoscopic scale structures of the basement gneisses in the Santana da Boa Vista region including sheath folds with NE-trending apex in low-strain zones (a) that are completely transposed in high strain zones (b). In the porphyritic monzogranites of the basement (c) high-strain fluid-rich deformation of $\mathrm{K}$-feldspar pophyroclasts and quartz segregation give rise to well-developed quartz mylonites $(\mathbf{d})$. Scales include a $10 \mathrm{~cm}$ long pen and a lens cap with $5 \mathrm{~cm}$ in diameter.

possível, ainda, observar-se porfiroclastos de feldspatos e sistemas de porfiroclastos de quartzo assimétricos (tipo sig$\mathrm{ma}$ ), indicando movimento do topo da sequência para $\mathrm{NE}$ e confirmando que as rochas supracrustais foram afetadas pela mesma deformação predominante no embasamento. Os vários estágios de deformação progressiva e as respectivas texturas e microestruturas desenvolvidas nestas rochas são apresentados em detalhe por Porcher \& Fernandes $(1993,1994)$.

A deformação tangencial, registrada nesta associação petrotectônica, é interpretada como tendo sido originada durante um importante episódio tectônico pós-colisional, responsável pela intercalação entre embasamento e cobertura ao longo de zonas de alta deformação sub-horizontais, com transporte paralelo ao alongamento do orógeno. Essa deformação tangencial tardia, denominada K2 por Fernandes et al. (1992a), mostra compatibilidade cinemática e de condições metamórficas com as zonas de transcorrência e granitóides sintectônicos mapeados nas associações de arco magmático, representando um evento deformacional posterior àqueles responsáveis pela estruturação da colagem e talvez associada ao colapso extensional do Cinturão Dom Feliciano (Porcher 1992). No entanto, a determinação das idades absolutas e trajetórias de P-T-t das tramas penetrativas nas zonas de cisalhamento tangenciais e transcorrentes, presentemente em andamento, são dados necessários para testar estas interpretações.

Associação de Arco Magmático II (AAMII) e ofiolitOS relacionados A Associação de Arco Magmático II (AAM II), aflorante na porção ocidental do Cinturão Dom Feliciano, é composta por uma suíte de granitóides orogênicos 
intrusivos em rochas máfícas e ultramáficas, tectonicamente intercaladas com uma sequência de metapelitos, quartzitos, mármores e grafita xistos (Figs. 9a-c). A suíte de granitóides orogênicos inclui os Gnaisses Cambai do Complexo Vila Nova (Silva $\left.F^{o} 1984,1994\right)$ e os granitóides metamorfisados do Complexo Cambai, na região de Lavras do Sul (Fernandes et al. 1992a,b, Kraemer et al. 1993a,b, Kraemer 1995). A descrição mais detalhada e a discussão do significado tectônico dessas rochas, originalmente incluídas nas formações Cambai, Cerro Mantiqueiras e Vacacaí (Goñi 1962), foi apresentada por Jost \& Villwock (1966) e, mais recentemente, por Remus (1990), na sua porção norte de afloramento, e por Tommasi et al (1994a), Tommasi \& Fernandes (1991) Fernandes et al. (1994, 1996) e Kraemer (1995),.na porção sul.

A suíte de granitóides orogênicos, de afinidade cálcioalcalina, inclui dioritos, tonalitos e trondhjemitos que registram o magmatismo originado pela subducção do assoalho oceânico da bacia marginal, num ambiente de margem continental ativa. As rochas máfico-ultramáficas incluem basaltos metamorfisados (anfibolitos) com características geoquímicas de 'P-MORB', leucogabros e harzburgitos com cromita podiforme, e são interpretadas como fragmentos de um ofiolito remanescente da crosta oceânica da bacia marginal. As rochas supracrustais são interpretadas como representando uma sequência sedimentar de assoalho oceânico (Fernandes et al. 1994).

A deformação e metamorfismo da fácies anfibolito a xisto verde, que afetaram essa associação petrotectônica, estão marcados por estruturas que podem ser reunidas em dois grupos principais. O primeiro, inclui as estruturas que marcam a trama principal formada durante o fluxo tectônico de mais alta temperatura e intensidade de deformação registrado por essas rochas. O segundo, de baixa temperatura, inclui as dobras abertas e falhas que afetam a trama originada durante o estágio anterior. A distribuição e a orientação preferencial dessas estruturas são apresentadas na figura 9c.

As estruturas formadas na sequência ofiolítica durante $o$ fluxo tectônico de alta temperatura e intensidade de deformação incluem lineações marcadas por agregados de ortopiroxênios, como pseudomorfos de cristais de piroxênios, mostrando orientação dimensional preferencial em harzburgitos metamorfisados (Fig. 10a). Lentes decimétricas de cromitito, com formas $\mathrm{X}>>\mathrm{Y}>\mathrm{Z}$ e eixo maior paralelo à lineação mineral, são igualmente observadas em peridotitos serpentinizados, apesar de raras. Nos basaltos metamorfisados (anfibolitos), a orientação dimensional de cristais de hornblenda e de plagioclásio são as lineações minerais mais comuns e marcam a direção de extensão. Estruturas planares nessas rochas incluem remanescentes de um bandamento decimétrico nos harzburgitos e um bandamento regular marcado pela alternância de bandas centimétricas ricas em plagioclásio e hornblenda nos anfibolitos (Fig.10b). Dobras isoclinais com limbos adelgaçados e charneiras espessadas mostrando orientação paralela às lineações são feições bastante comuns. Dobras pigmáticas são frequentemente observadas em veios de leucodioritos e trondhjemitos discordantes do bandamento.

A sequência supracrustal que aflora ao sul dessa área exibe uma trama de fácies xisto verde característica para cada litodema. Nos metapelitos, a trama parece ser predominantemente retrogressiva, como indicado pela presença de relictos de porfiroblastos pré-tectônicos (estaurolita ?). Esta trama é afetada por dois conjuntos de dobras isoclinais a apertadas com charneiras orientadas preferencialmente E-W.
Litoclastos com foliação interna ('peixes de foliação') observados nos mármores são os indicadores cinemáticos mais confiáveis observados nessas rochas, e, retirados os efeitos das dobras tardias, mostram um transporte tectônico do topo da sequência para oeste.

Os diversos granitóides orogênicos mostram estruturas semelhantes entre si, sendo, portanto, descritas em conjunto. Os dioritos apresentam remanescentes de uma foliação magmática em lentes de baixa deformação, marcada pela orientação dimensional de cristais de plagioclásio e anfibólio com baixo caimento e direção E-W. Nas zonas de alta deformação, esta trama é transformada em um bandamento composicional de espessura centimétrica a decimétrica, com dobras intrafoliais abundantes, mostrando charneiras paralelas às lineações minerais e de estiramento. Tramas tectônicas semelhantes a essa são observadas nos tonalitos e trondhjemitos. Nesses celtimos, a presença de uma trama $\mathrm{L}>\mathrm{S}$ marcada por mullions (Fig.10c) e enclaves máficos deformados sugere a predominância local de deformação constritiva.

Excetuando-se os peridotitos, que mostram evidências de um fluxo de temperaturas muito elevadas (Tommasi et al. 1994), a deformação da fácies anfibolito à xisto verde caracteriza a trama composta em todos os demais litodemas da associação petrotectônica. Essa trama mostra uma atitude original sub-horizontal, apresentando lineações minerais e de estiramento de baixo caimento e direção E-W, que são perturbadas ou pelas dobras tardias que controlam a distribuição regional da foliação ou pelas zonas de cisalhamento transcorrente dextrais com direções NW (Falha de Ibaré) e sinistrais com direção NE. Os poucos indicadores cinemáticos observados apontam a direção E-W como sendo a do transporte tectônico, mas com sentidos de movimento opostos (topo da sequência para leste e oeste).

A reconstituição geométrica e estudos da trama das rochas dessa associação petrotectônica são dificultados pela carência de exposição e pela ocorrência de um evento de recristalização pós-tectônica, responsável pela textura granoblástica poligonal e desaparecimento das feições de deformação intracristalina. No entanto, isso não inviabiliza a interpretação de que a trama composta, registrada em todos litodemas desta associação, foi originada durante um fluxo tectônico sob condições de temperatura decrescente. De acordo com esta interpretação, os pseudomorfos de ortopiroxênio nos harzburgitos da sequência ultramáfica marcam a direção de fluxo no manto durante os estágios iniciais da deformação principal (Tommasi et al. 1994a), enquanto que as lineações minerais e de estiramento das demais unidades constituem-se em evidências das temperaturas mais baixas (fácies anfibolito a xisto verde, como evidenciado pelas paragêneses e microestruturas), características dos estágios finais dessa deformação. Milonitos feldspáticos e quartzo-milonitos, marcando uma das raras zonas de cisalhamento de escala regional mapeada ( $c f$. Fig.9c), foram desenvolvidos durante este episódio. Dobras apertadas a isoclinais observadas nas rochas supracrustais e nos xistos magnesianos são atribuídas aos estágios finais dessa deformação, sendo, portanto, tratadas como parte da trama ( $c f$. Fernandes et al. 1991).

A foliação composta, registrada por todas as unidades da Associação de Arco Magmático II e, também, pelas sequências de rochas máfícas e sedimentares intercaladas, foi interpretada como tendo sido originada ao longo de uma zona de cisalhamento de escala litosférica, responsável pela intercalação tectônica de 'lascas' do manto oceânico da bacia margi- 

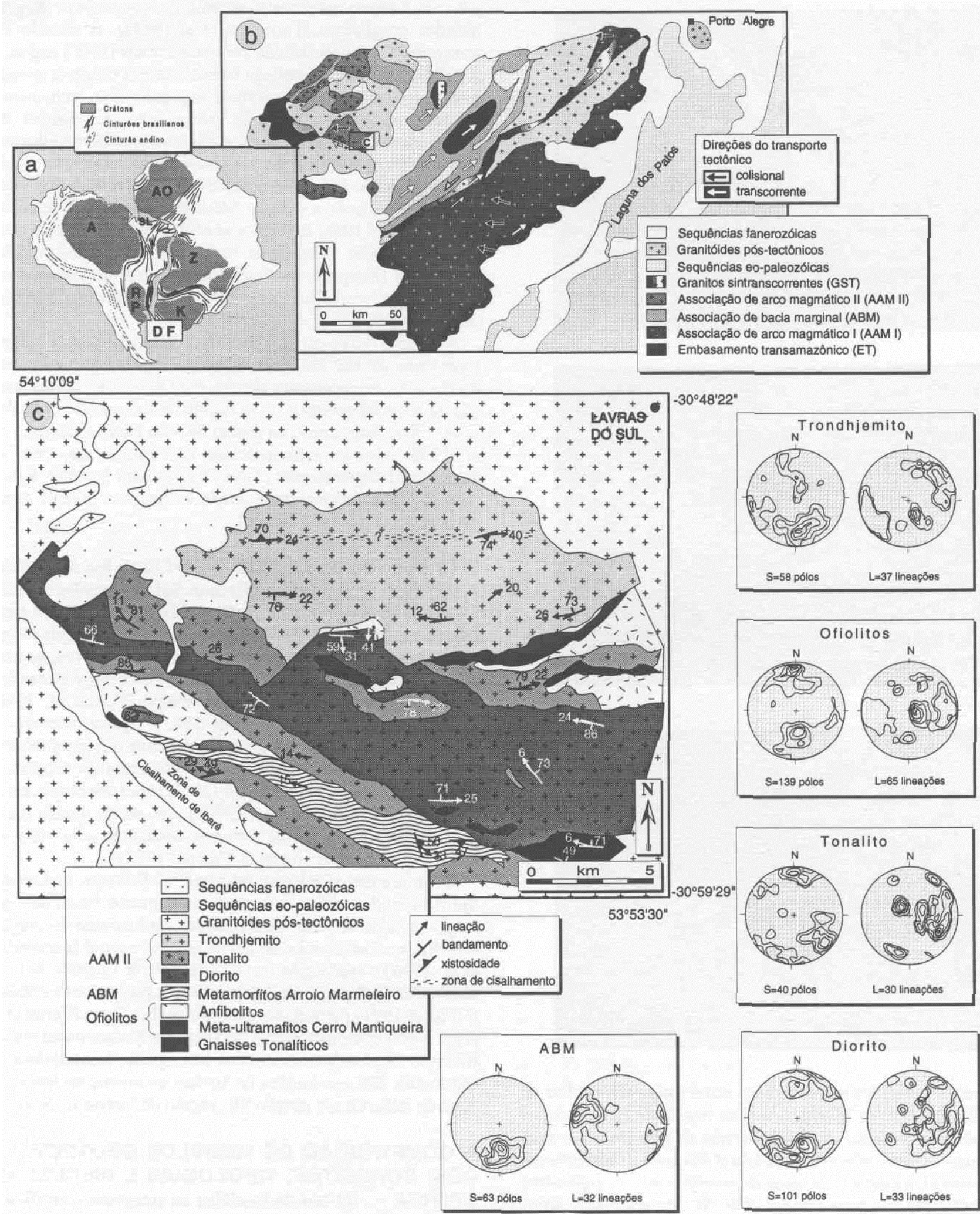

Figura 9 - Unidades do Sistema Geodinâmica do Gondwana Oeste durante o Neoproterozóico (a) incluindo o mapa simplificado das associações petrotectônicas (b). Mapa Geológico da região de Lavras do Sul na porção oeste do Escudo Sul-rio-grandense (c) onde afloram litodemas da Associação de Arco Magmático II e remanescentes da crosta oceânica da bacia marginal (rochas ultramáficas e vulcano-sedimentares), com estereogramas mostrando a orientação das principais estruturas. Figure 9 - Tectonic situation of the Dom Feliciano Belt (DF) in relation to the units of the Gondwana Geodynamic System during the Neoproterozoic (a), including a simplified map of the lithotectonic assemblages of the Dom Feliciano Belt (b). Geological map of Lavras do Sul region in the western part of Sul-rio-grandense shield (c) where lithodemes of the Magmatic Are Assemblage II (AAM II) and remnants of the oceanic crust of the marginal basin crop out. Stereonets show the orientation of the high-T foliation and associated stretching and mineral lineations. 

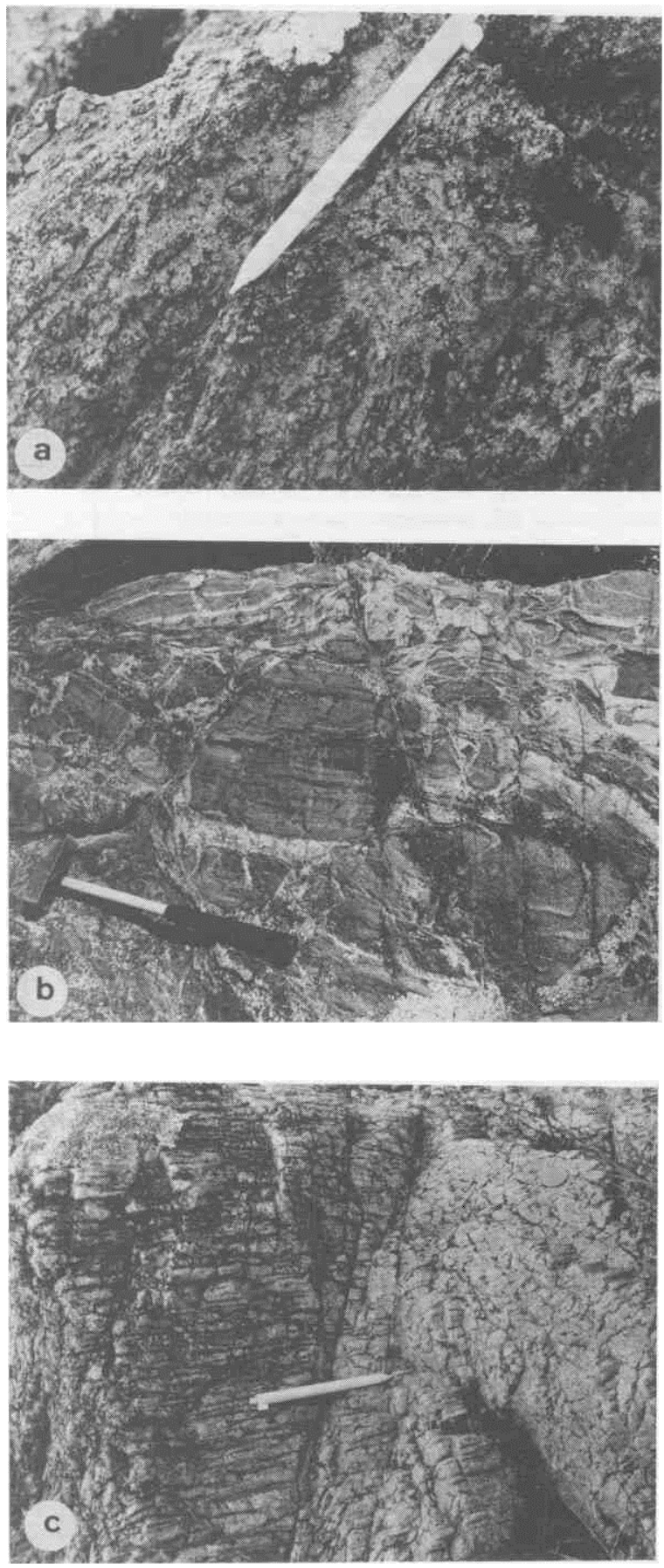

Figura 10 - Feições mesoscópicas observadas nas rochas da Associação de Arco Magmático II na região de Lavras do Sul incluem a orientação de pseudomorfos de piroxênio nos harzburgitos metamorfisados, paralela à lineação de estiramento regional (a), a intrusão de veios de leucodiorito nos anfibolitos bandadas (b) e a trama linear $(L>>S)$ originada por deformação (constritiva) dos metatrondhjemitos (c). As dimensões das escalas são de $15 \mathrm{~cm}$ para a caneta e de $45 \mathrm{~cm}$ para o cabo da marreta.

Figure $1 \mathrm{O}$ - Mesoscopic-scale structures observed in rocks of the Magmatic Are Assemblage II and Lavras ophiolites include the orientation of pyroxene pseudomorphs parallel to the regional lineations (a), intrusive breccia of leucodiorite in banded amphibolite (b) and the stretching lineation $(\mathrm{L}>>\mathrm{S})$ formed during constrictive) deformation of the metamorphosed trondhjemites (c). Dimensions of scales are 15 and $45 \mathrm{~cm}$ for the pen and hammer, respectively. nal com a crosta continental juvenil, representada pelos granitóides orogênicos (Tommasi et al. 1994a). A direção de transporte tectônico exibida por estas rochas (E-W) sugere a possibilidade de uma colisão frontal entre a colagem orogênicae a margem continental ativa, seguindo-se ao fechamento da bacia marginal ( $c f$. Fig.2). Além disto, associações de rochas mostrando composição e idades bastante semelhantes às das presentemente descritas, que afloram na porção setentrional da AAM II (região de Vila Nova), apresentam tramas orientadas segundo a direção NE-SW (Silva P \& Soliani Jr. 1987, Silva $F^{0}$ 1994, Babinsky et al. 1996). Tramas com essa orientação estão, geralmente, associadas com a deformação tardia com transporte tectônico paralelo ao alongamento do orógeno que retrabalham as unidades da colagem ( $c f$. Fernandes et al. 1992a).

As idades (U/Pb-zircão) de 737+ 7 Ma, para os anfibolitos, e em torno de $722 \mathrm{Ma}$, para os granitóides orogênicos metamorfisados, recentemente obtidas para as rochas da Associação de Arco Magmático II, na região de Lavras do Sul (Leite et al. 1995), bem como na região de Vila Nova (Babinsky et al. 1996), embora mais precisas, são consistentes com as datações Rb/Sr existentes (Silva P \& Soliani Jr. 1987, Kraemer 1995), confirmando a idade e natureza juvenil desta associação de rochas (Tab. Ic).

O Cráton Rio de La Plata O Cráton Rio de La Plata (CRP) está representado no Escudo Sul-rio-grandense pelas rochas de fácies granulito do Complexo Santa Maria Chico (Hartmann \& Nardi 1983). Litodemas desse complexo incluem tonalitos, trondhjemitos, gnaisses básicos, rochas metassedimentares, rochas ultrabásicas e anortositos metamorfisados durante o Ciclo Transamazônico (Soliani Jr. 1986, Hartmann 1987, Mantovani et al. 1987). Apesar da carência de estudos acerca dessas rochas, as mesmas são interpretadas como representantes das raízes de um cinturão orogênico paleoproterozóico (2200 Ma, cf. Tab. Id) com orientação geral NW-SE ( $c f$. Fernandes et al. 1992b), que ocupa grande parte do Uruguai, limitado dos terrenos arqueanos pela zona de falha Sarandi-del-Yi (Bossi \& Campal 1992).

O limite entre o CRP e o Cinturão Dom Feliciano no Escudo Sul-rio-grandense tem sido tradicionalmente localizado ao longo da Falha de Ibaré, uma zona de cisalhamento de direção NW-SE, com evidências de deslocamento dextral (Fernandes et al. 1996) e reativação sinistrai (Fig.9c \& Luzardo \& Fernandes 1990). No entanto, mapeamentos geológico de detalhe (UFRGS 1991) e estudos estruturais preliminares (Fernandes et al. 1996) demonstraram a inexistência de diferenças significativas entre as características litológicas, metamórficas e estruturais das associações de rochas de ambos os lados da zona de falha na sua porção SE (região de Lavras do Sul).

\section{A CONSTRUÇÃO DE MODELOS GEOTECTÔNI- COS: CONCEITOS, TIPOLOGIAS E DISCUSSÃO CRÍTICA $O$ uso de modelos na pesquisa científica e geológica: para quê? A revolução científica iniciada com a teoria da tectônica de placas, no final da década de 60 , mudou completamente a lógica da descoberta científica na Geologia. De uma ciência tradicionalmente observacional-indutivista, a Geologia passou a ser uma ciência dedutiva-crítica, cujas teorias são testáveis e modelizáveis nas mais diferentes áreas e escalas de análise ( $c f$. Menegat 1994). O teste de modelos passou a ser o cerne da fabricação científica, implicando não só uma série de técnicas de modelagem e de computação, mas,}


principalmente, uma nova estruturação entre as teorias e os dados ( $c f$. Menegat \& Fernandes 1995). Esse esforço acelerou a produção geocientífica em termos quantitativos e qualitativos ( $c f$. Menegat \& Fernandes 1993a). Já não se trata de aplicar uma lista infalível de passos a serem seguidos, como apregoavam os manuais da década de 60, mas saber identificar e resolver problemas utilizando a integração de técnicas e hierarquização de dados.

Nesse novo contexto, a Geologia pode acompanhar a mutação epistemológica ocorrida na Ciência enquanto um todo, a qual substituiu os antigos critérios de verdade e prova das teorias científicas (Prigogine \& Stengers 1991). Entendidas hoje como verdades falíveis, as teorias já não podem ser provadas, mas sim testadas e corroboradas.(Popper 1989). Condição para a boa ciência, as teorias devem possuir alto grau de predição e parcimonia, razão pela qual o empreendimento científico passa, ele mesmo, a ser entendido enquanto uma estrutura (Stegmüller, 1983) que, por sua vez, pode ser estipulada enquanto um modelo de um programa de pesquisas, na linguagem de Lakatos (1979), ou de um paradigma, para Khun (1989). A ciência progride devido ao desenvolvimento, correção e substituição desses modelos e programas de pesquisa.

Com o desenvolvimento de teorias como a da Tectônica de Placas, é possível representar e explicar os fenómenos da Terra a partir do todo, inclusive, reproduzindo-os a partir de modelos matemáticos sofisticados, como a teoria das catástrofes e sistemas dinâmicos (Thom 1975, Mandelbrot 1977, Lakatos 1987). Os resultados assim obtidos contrastam com a visão empirista da Geologia, que descrevia e explicava a realidade de modo fragmentado, reduzindo-se a técnicas observacionais passíveis de generalização, quando possível, pelo método indutivo. Distantes de serem definitivos, os modelos geológicos, em geral, e os geotectônicos, em particular, são construídos para serem continuamente testados e refutados. No limite, esses testes podem vir a refutar todo um Programa de Pesquisas (ou um Paradigma) estabelecido durante um certo intervalo de tempo pela comunidade científica. As teorias e modelos assumidos como verdades falíveis, passam, assim, a mudar rapidamente. Novos problemas e testes são continuamente estabelecidos, podendo tornar a atividade científica mais crítica e menos dogmática em relação aos seus pressupostos e resultados (Bachelard 1934).

Neste sentido, o cenário da pesquisa geológica mudou dramaticamente de uma situação de coleta acumulativa, linear e contínua de dados, para outra, com muitas descontinuidades estruturais resultantes da nova relação existente entre os dados e as teorias. Essas duas possiblidades ainda coexistem na comunidade geocientífica e se expressam por duas maneiras distintas de construir-se modelos. Os primeiros, entendem os modelos como sendo uma cópia fiel da realidade, como se fossem uma maquete. Os segundos, entendem que os modelos são também uma forma de estruturar a relação entre as teorias e dados em termos de uma visão indissociável. Assim, pode-se chamar esses celtimos de modelos teóricos, como é o caso da Tectônica de Placas.

Os modelos como cópia da realidade são descritivos, locais, parciais e imediatos à observação. Não são parte essencial de uma teoria, mas sim de uma técnica particular de se medir ou representar a realidade. Portanto, podem vir a ter utilidade psicológica e força heurística e, às vezes, constituem-se mais como metáforas do que explicações de um fenómeno (Hesse 1965). Desenhos, diagramas e classificações podem ser considerados como modelos descritivos. Neste grupo, destacam- se os modelos analógicos, os quais procuram copiar o objeto real em alguma propriedade sua (densidade, forma, volume, etc.), de modo que se possa obter um análogo. Na medida em que o modelo analógico repete uma dada configuração esperada, podemos dizer que tal configuração é possível no mundo real. Contudo, tais modelos não possuem o estatuto epistemológico de comprovação de uma teoria e são o tipo de modelo, por excelência, adotado pelas epistemologias empiristas, pois respondem muito mais às necessidade individuais do pesquisador.

Os modelos teóricos prendem-se à evolução do conhecimento de uma ciência e não variam arbitrariamente. Constituem-se em um conjunto de enunciados graças ao qual é possível integrar-se a convergência da teoria e da experiência (observação) num discurso cénico (Badiou 1989). Tais modelos unificam a desordem instantânea do conhecimento em formas diversas de integração, sendo, portanto, transitórios, isto é, destinam-se ao seu próprio desmantelamento. Partem do pressuposto de que o todo possa ser modelizável enquanto sistema dinâmico (Thom 1975). O modelo está diretamente vinculado com a teoria e ela o tem como algo logicamente existente e verdadeiro, de tal sorte que, se o resultado for existente e verdadeiro, a teoria também o será (Lakatos 1987). A condição de testabilidade que se faz necessária é a de que a cada evidência possa corresponder um enunciado derivável do sistema e, a cada enunciado derivável do sistema possa corresponder uma evidência. Deste modo, esses modelos possuem alta capacidade preditiva dos fenómenos e podem ser avaliados quanto ao seu grau de realismo, precisão e generalidade. Tais relações podem ser expressas, também em termos de modelos matemáticos, os quais são construídos a partir da parametrização de mecanismos em espaços desde euclideanos, até topológicos e de Hilbert, nos quais é possível realizar uma análise global partindo do todo (Thom 1975). Assim, os modelos teóricos, que por isso, são indissociáveis da observação, atendem os aspectos coletivos da produção científica, e não aos individuais como supunha a epistemologia empirista.

Desta forma, torna-se interessante pressupor que o progresso da pesquisa na geologia tem-se dado cada vez mais em termos do desenvolvimento de uma metodologia de construção teórica de modelos dinâmicos. Como decorrência, uma das mudanças epistêmicas fundamentais da Geologia contemporânea têm sido relacionada com a mudança na forma de narrar a História da Terra, que se cindiu profundamente dos elementos teológicos-metafísicos que a originaram, para tornar-se uma explicação construída em termos da evolução de processos geológicos hierarquizados segundo sua significância crono-geodinâmica passível de ser testada empiricamente. A História da Terra perdeu, assim, sua característica épicanaturalista-descritiva, que era estruturada em termos de uma sucessão de eventos sem relação causal intrínseca. A nova narrativa passa, agora, a ser estruturada segundo uma evolução de sistemas dinâmicos, onde cada evento possui a memória do anterior bem como as possíveis condicionantes do evento seguinte, podendo-se, então, modelizá-los e falseá-los com os diferentes registros gerados, tanto em nível global como local.

Características dos modelos derivados da Tectônica de Placas: conceitos e nomenclatura utilizados Descortinar a proposição e a falência dos modelos geológicos é, em outros termos, perguntar: Qual o papel dos modelos na metodologia da pesquisa geoló gica? Quais os 
critérios para mudá-los? Como são refutados? Como são construídos? Os modelos são mera especulação e, neste caso, o importante mesmo são os dados ou há uma lógica nisso tudo? Enfim, é possível coligir-se dados em geologia sem o uso de modelos? Em outras palavras, pode-se separar a dita "Geologia de Campo" da "Geologia das Teorias"?

A nossa tese é a de que não há como cindir o dado da teoria, isto é, toda a observação é carregada de teoria (Popper 1989), bem como toda a teoria, para ser científica, deve ser passível de teste pela observação. A cénica forma de mediar-se esta relação é através do uso de modelos como forma de estruturarse a pesquisa e, portanto, o conhecimento.

Certamente, há uma possibilidade infindável de arranjarmos os dados geológicos com modelos geológicos. Mas, o problema principal é saber se o modelo que estamos utilizando tem grande potencial explicativo de um volume avantajado de dados, obteníveis por diversas técnicas e métodos. Isto é, o modelo tem alto potencial para ser falseado, ou seja, ele sofre o impacto dos dados e, com isso, progride, se dinamiza, mas mantém o programa de pesquisas. Quando, pelo contrário, os dados se arranjam facilmente no modelo, ou o abandonamos rapidamente, sem tê-lo passado por uma trajetória de testes, então não se manteve um programa de pesquisas. Neste caso, a pesquisa científica é entendida como uma "colcha de retalhos" estabelecida por tentativa-e-erro. Os modelos passam a não ter importância para a estruturação do conhecimento, pois no fundo, essa praxiologia científica ainda preconiza a separação entre dados e teorias-modelos.

Neste sentido, enfatizar-se-á na presente discussão os modelos derivados da Tectônica de Placas. Isto, não somente por ter sido este o programa de pesquisas mais testado da história das geociências (Allègre 1988), estando atualmente muito bem corroborado ( $c f$. Hilde \& Carlson 1991), mas, principalmente, porque esses modelos tem sido capazes de promover grandes avanços na investigação da evolução geológica do Escudo Sul-rio-grandense.

Já os modelos que se utilizam de elementos da Tectônica de Terrenos e de Plumas Mantélicas, apesar de mais recentes, por não apresentarem uma consistência minimamente compatível com a sua própria base empírica, como no caso particular dos aplicados à evolução tectônica do escudo (e.g. Hartmann et al. 1994, Fragoso-César et al. 1994,1995) não são discutidos nesse trabalho. A maior parte dos mesmos, possivelmente efémeros no caso do RS, carecem de consistência dedutiva e capacidade de predição, além de apresentarem outras dificuldades intrínsecas ao seu arcabouço conceituai, que acabam por dificultar a sua utilização ( $c f$. Sengör \& Dewey 1990).

Segundo Sengör (1991) a Tectônica de Placas permite uma definição e hierarquização temporal e espacial dos eventos geológicos responsáveis pela estruturação de um orógeno, de modo que modelos deste tipo possibilitam a realização de uma "anatomia detalhada dos cinturões de montanhas". Apresentam igualmente uma alta capacidade de predição e consistência dedutiva, características essenciais e necessárias para o estabelecimento de um programa de pesquisas ( $c f$. Menegat $\&$ Fernandes 1995). Por terem sido capazes de fornecer um arcabouço teórico adequado, serem intrinsicamente melhor delimitados e portanto mais facilmente testáveis, tem sido aplicados com sucesso na investigação geológica do escudo nos celtimos 15 anos (Ribeiro \& Fantinel 1978, Fragoso-César 1980, Jost 1981, Fragoso-César et al. 1982,1984,1986,1991, Tommasi \& Fernandes 1990).
Os modelos tectônicos propostos para o Cinturão Dom Feliciano podem ser claramente diferenciados em função do arcabouço teórico-conceitual adotado e da base geológica utilizada em cada um dos mesmos. No caso da presente contribuição a abordagem adotada é claramente atualista e segue a nomenclatura sistematizada por Sengör (1990a,1991). Segundo esta, um cinturão orogênico constitui-se de uma colagem orogênica composta por diversas associações petrotectônicas. Estas celtimas são consideradas como unidades fundamentais dos orógenos e entendidas como um conjunto de associações de rochas compatíveis em termos de petrogênese e idades, e formadas por um determinado processo tectônico, ocorrendo espacialmente associadas, sendo diagnosticas de um ambiente geotectônico específico. De acordo com estas concepções, uma "... zona ou colagem orogênica é o resultado da atividade de um grande ncemero de limites de placas convergentes no espaço e no tempo..." sendo invariavelmente estruturada durante um intervalo de tempo geológico relativamente longo, através do desenvolvimento de diversas orogenias (Sengör 1991, p.319).

Uma colagem ou cinturão orogênico, que no caso dos exemplos fanerozóicos é uma entidade morfo-tectônica, compreende, além de associações petrotectônicas representativas de adição crustal juvenil, como arcos magmáticos intraoceânicos, magmatismo de margem continental ativa, ofiolitos e remanescente de prismas acrescionários, porções de crosta mais antiga, que apresentam graus de retrabalhamento variável durante as orogêneses responsáveis pela estruturação do cinturão. A crosta mais antiga, invariavelmente presente em colagens orogênicas das mais diversas idades, pode ter sido formada ou durante um ciclo orogênico anterior, tratando-se, nesse caso, de uma porção do embasamento; ou mesmo durante um episódio tectônico imediatamente mais antigo, embora ainda relacionado ao mesmo ciclo orogênico, como proposto para os granitóides orogênicos mais antigos da região leste do CDF. No entanto, o essencial no estudo da compartimentação tectônica de um orógeno é distinguir-se a natureza, características e estratigrafia interna de cada uma das associações de rochas que compõem o mesmo, bem como as idades relativas e absolutas das rochas dessas associações. Todos esses fatores dependem, cénica e inteiramente, da história evolutiva particular de cada cinturão.

A concepção tectônica e nomenclatura esboçada acima é diversa da atualmente adotada pela maioria dos autores que tem preconizado que as rochas do Escudo Sul-rio-grandense pertencem a mais de um orógeno, incluindo (de E para W) os cinturões: Dom Feliciano, Tijucas e Vila Nova (cf. FragosoCésar et al. 1994, 1995, Chemale et al. 1994, Babinsky et al. 1996). Essas interpretações, fortemente baseadas em dados geocronológicos não sistemáticos, enfatizam as diferenças de idades e dos valores de $\varepsilon \mathrm{Nd}(\mathrm{t})$ entre as regiões leste e oeste do escudo (Mantovani et al. 1987, Babinsky et al. 1996). No entanto, embora os dados radiométricos da região oeste tenham um excelente controle geológico ( $c f$. Silva $\mathrm{P}$ 1984, 1994), as idades Sm/Nd (600-610 Ma- Babinsky et al. 1995) e $\mathrm{Pb} / \mathrm{Pb}$ (572-616 Ma) obtidas para os gnaisses de região leste, provém de exposições nas vizinhanças da localidade de Pinheiro Machado (Chemale et al. 1995a,b), a poucos quilómetros da área de afloramento dos granitóides sintranscorrentes.

Esses dados não seriam incompatíveis com as interpretações de que as idades de c. 600 Ma correspodem à 'Orogenia Dom Feliciano', mais jovem do que à 'Orogenia Vila Nova', 
à oeste; e que aquela 'orogenia' seria responsável pelo retrabalhamento de crosta mais antiga, sem adição significativa de material juvenil (Chemale et al. 1995a, 1996), não fossem dois importantes problemas de consistência entre as idades obtidas e a evolução geológica da região. Senão, vejamos. O primeiro, refere-se à coincidência desses valores com as idades $\mathrm{Sm} / \mathrm{Nd}$ para granitos sub-alcalinos pós-(Granito Encruzilhada-595 \pm 5 Ma) e tardi-transcorrência (Granito Arroio Moinho-596 \pm 1 $\mathrm{Ma}$ ), obtidas na mesma região por esses autores (Babinsky et al. 1995). O segundo, é atinente à similaridade das cifras obtidas com as idades magmáticas (Rb/Sr-RT), determinadas para os granitos peraluminosos sintranscorrência, cuja origem, a partir de fusão das rochas encaixantes ao longo da zona de transcorrência, parece estar atualmente bem estabelecida (cf. Frantz \& Nardi 1992a,b, Koester 1995, Koester et al,1996).

Finalmente, a presença de gnaisses do embasamento paleoproterozóico na porção central do escudo e a correlação da porção oeste com o Cinturão Ribeira (SP e PR), são outros dos principais critérios utilizados para a divisão das rochas do escudo como pertencentes a cinturões diferentes (e.g. Fragoso-César 1991, Chemale et al. 1994a, b). Tal correlação é temerária mesmo entre regiões tão próximas como o Escudo Catarinense. $\mathrm{O}$ alto gravimétrico na porção norte desse escudo, correspondente ao granulitos de Luiz Alves foi inadequadamente correlacionado com o bloco geofísico centralleste do Escudo Sul-rio-grandense (Shukovsky et al. 1991, Fragoso-César et al. 1995), onde as rochas supracrustais da Associação de Bacia Marginal são responsáveis pela anomalia gravimétrica.

Capacidade preditiva e explicativa: um modelo para o Cinturão Dom Feliciano A interpretação presentemente adotada postula, no entanto, que os cinturões Dom Feliciano e Vila Nova (sensu Fragoso-César 1991 e Chemale et al. 1994a,b) correspondem à associações petrotectônicas (arcos magmáticos) de uma colagem orogênica cénica: a do Cinturão Dom Feliciano (CDF). Essa denominação, embora inadequada, deve ser mantida, por estar consagrada na literatura. Esse modelo proposto para o CDF se caracteriza pelo uso de nomenclatura e conceitos universalmente aceitos (cf. item acima), é capaz de integrar a teoria e as observações da maneira mais parcimoniosa possível, sem redução significativa da sua precisão e capacidade preditiva ( $c f$. Menegat 1994). Característica acessória, mas não menos importante desse modelo, é evitar a proliferação de denominações inadequadas, como a de 'cinturão', para designar associações de rochas que seriam mais apropriadamente interpretadas como associações petrotectônicas. Isso porque, embora de génese e história evolutiva complexa, podem ser perfeitamente relacionadas a um determinado ambiente geotectônico, mapeadas na escala de semi-detalhe (1:50.000) e classificadas em litodemas, suítes e complexos de acordo com as normas estratigráficas adotadas internacionalmente (e.g. Sohl 1977, Hattin 1991 e referências nesses).

Além disto, de acordo com o modelo aqui apresentado, as evidências para a presença de crosta mais antiga podem ser explicadas em termos da natureza de margem continental ati vá para os dois arcos magmáticos, principalmente no caso da AAM I, interpretada como tendo sido originada por subducção da crosta oceânica sob uma espessa margem continental (Fig.2; Fragoso-César et al. 1986, Figueiredo et al. 1990). As características isotópicas refletiriam, assim, o maior ou menor envolvimento do embasamento nos processos petrogenéticos (principalmente os magmáticos) em ambas as regiões. Isto é aparentemente confirmado pelos dados isotópicos disponíveis, indicando ter havido uma contribuição extremamente restrita de crosta siálica mais antiga no domínio oeste (e.g. Leite et al. 1995, Chemale et al. 1996,Remus et al. 1995, 1996), onde há o registro de ter ocorrido o predomínio da adição de material juvenil à crosta, em contraposição às evidências geoquímicas, as quais apontam um envolvimento maior do embasamento no domínio leste (Basei 1985, Mantovani et al. 1987, Chemale et al. 1995b, 1996).

Retrabalhamento de crosta siálica mais antiga, como foi aparentemente o caso da margem continental ativa na porção leste do escudo (AAM I), não significa que se trata de uma situação tectônica incompatível com um modelo que utiliza princípios e conceitos da Tectônica Global. Inversamente, o envolvimento de crosta continental pré-existente é uma situação muito comum em orógenos das mais diversas idades, principalmente nos cinturões fanerozóicos, onde a disponibilidade de dados de paleomagnetismo, distribuição e mecanismos focais de terremotos, preservação de evidências de subducção e de grande parte das associações petrotectônicas não deixam dcevidas quanto a sua origem a partir da convergência de placas litosféricas. Nesses cinturões, geralmente com excelente exposição, algumas das associações petrotectônicas, como ofiolitos e prismas acrescionários, mesmo quando preservadas, constituem porções diminutas do volume total de rochas expostas. Este problema é ainda mais crítico no caso de grande parte dos orógenos serem mais antigos e de pior exposição. Nesses, o registro geológico é geralmente menos completo devido às maiores possibilidades de obliteração por processos tectônicos e erosivos posteriores, significando que associações de rochas de determinados ambientes geotectônicos têm suas chances de preservação drasticamente reduzidas (e.g Platt 1990). A ausência de um registro geológico produzido por determinados processos não significa, m continenti, que um modelo tectônico como do tipo 'Ensiálico', por exemplo, seja mais adequado para explicar a evolução tectônica dos mesmos, em geral, e, muito menos, do Cinturão Dom Feliciano (CDF), em particular.

Cinturões ensiálicos: origem e dilemas do conceito Modelos tectônicos caracterizados por um envolvimento restrito ou mesmo ausente de litosfera oceânica na evolução de orógenos, mais conhecidos como 'ensiálicos', foram utilizados para explicar a evolução tectônica de associações do pré-Cambriano em diversos continentes na década de 70 e 80 (principalmente na çfrica e no Brasil), sendo ainda hoje bastante disseminados. No entanto, esse conceito originou-se no início do século, durante o mapeamento dos terrenos gnáissicos NW da Escócia (Peach et al. 1907). Essa região é caracterizada pela existência de um fragmento de crosta mais antiga, representada pelos gnaisses arqueanos do Scourian Complex que afloram na região conhecida como Central Belt. Essas rochas, juntamente com uma cobertura vulcano-sedimentar mais nova, sofreram intenso retrabalhamento tectônico durante o paleo-Proterozóico (Inverian \& Laxfordian Orogenies) formando as regiões conhecidas como northern e southern belts.

Cinquenta anos mais tarde, uma versão mais evoluída deste conceito foi novamente utilizada para interpretar a evolução das rochas pré-Cambrianas da mesma região (Suton \& Watson 1951), de onde foi estendido para as demais áreas do Cráton 
do Atlântico Norte, principalmente o escudo da Groenlândia (Complexo Gnáissico Arqueano e Cinturão Nagssugtoqidian) e Escudo Canadense. Nessa mesma época, a extensão do conceito de retrabalhamento da crosta continental para explicar a evolução tectônica dos cinturões da África do Sul e Namíbia, após ter sido introduzido por MacGregor (1951), evoluiu de dois modos diversos em diferentes épocas da investigação dos terrenos pré-Cambrianos.

$\mathrm{O}$ primeiro modo, predominante entre as décadas de $50 \mathrm{e}$ 70 , conduziu ao desenvolvimento do denominado 'modelo ensiálico'. Essa concepção se alicerçava, principalmente, em evidências como (a) abundância de embasamento siálico retrabalhado, (b) pequena proporção relativa de rochas máficas, (c) presença de sequências mioclinais sobrepostas discordantemente ao embasamento mais antigo, (d) continuidade dos trenas de estruturas mais antigas através de cinturões mais novos, além de (e) dados de paleomagnetismo indicando a inexistência de grandes deslocamentos entre blocos cratônicos nesses cinturões (e.g. Kennedy 1964, Kršner 1981). Este modelo, no entanto, não resistiu às investigações dos anos 80 , quando a utilização de técnicas isotópicas capazes de reconhecer a natureza e idade das associações de rochas apesar das trasformações relacionadas ao metamorfismo e deformação que apresentam. Simultaneamente, a consolidação da Tectônica Global favoreceu o reconhecimento, nesses cinturões, de características compatíveis com a existência pretérita de crosta oceânica e a atuação de um regime 'mobilista'. Isso foi deduzido a partir do reconhecimento da existência de batólitos cálcio-alcalinos e suturas com ofiolitos (cf. Windley 1984) ou crípticas, detectáveis apenas através da aplicação de isótopos estáveis (e.g. Kalsbeek et al. 1987,Kalsbeek\&Nutman 1996), além de uma evolução tectônica e metamórfica compatível com as apresentadas pelos cinturões fanerozóicos. A acresção continental durante a evolução de diversos cinturões anteriormente interpretados como ensiálicos, tem sido desde então inequivocamente demonstrada (e.g. Krsner 1991, Myers \& Krõner 1994), mesmo para os exemplos clássicos de cinturões 'ensiálicos' como é o caso do Damara (Kukla \& Stanistreet 1991).

O segundo modo de evolução do conceito de retrabalhamento de crosta mais antiga, utilizado principalmente a partir da metade da década de 70 , conduziu às interpretações dos cinturões pré-Cambrianos como Mobile Belts ou 'Faixas Móveis', genericamente definidos como 'cinturões metamórficos de médio a alto grau com formação de migmatitos e granitos sintectônicos, deformação policíclica e intenso retrabalhamento do seu embasamento siálico mais antigo' (Cordani 1968). Entretanto, com os avanços do entendimento dos processos tectônicos impulsionados pela consolidação de um paradigma geológico crono-geodinâmico e arcabouço conceituai como o fornecido pela Tectônica de Placas, houve, nos anos 80 , uma crescente preocupação com a cinemática dos processos tectônicos. A partir de então, passou a ficar evidente que os deslocamentos de maior magnitude, atingindo a ordem de centenas de quilómetros, ocorrem paralelamente ao alongamento dos orógenos (Sengör 1991), sendo, com poucas excessões como é o caso da acresção de terrenos, tardios em relação à estruturação das colagens. A denominação mobile, anteriormente utilizada em referência às evidências de intensa deformação, foi reconhecida como tratando-se de translação de massas rochosas paralelamente ao alongamento do cinturão. Esta constatação foi confirmada pelos dados sobre a evolução cinemática dos cinturões Pan-Africanos, em particu- lar, conduzindo à interpretação de grande parte dessas estruturas como zonas de cisalhamento transpressivas de grande escala (Coward 1980), no interior das placas (cf. Vauchez \& Nicolas 1991), ou limitando placas continentais (Coward \& Daly 1984, Daly 1988). No entanto, o reconhecimento nesses cinturões, de associações petrotectônicas semelhantes às observadas nos cinturões orogênicos fanerozóicos, possibilitou a inserção dos mesmos num contexto de Tectônica Global, permitindo, ainda, a interpretação do padrão longitudinal das lineações de estiramento, que registram a direção de translação das massas rochosas, como resultado da direção de movimentação relativa de placas litosféricas,em alguns casos, decorrente de colisões oblíquas (e.g. Shackleton \& Ries 1984).

O modelo ensiálico para o Cinturão Dom Feliciano: a fragilidade das evidências No caso particular do CDF, os modelos não-atualistas se sustentam além dos dados de isótopos, como anteriormente comentado, pelo fato de que somente as rochas de baixo grau dos cinturões e os granitos sub-alcalinos tardios (dos quais foram obtidas as primeiras datações radiométricas $\mathrm{K}-\mathrm{Ar}$ e $\mathrm{Rb}-\mathrm{Sr}$ ) eram historicamente considerados como originados durante o 'Ciclo Brasiliano' . Neste caso, as rochas plutônicas cálcio-alcalinas e os gnaisses de alto grau eram denominadas de migmatitos, sendo, então, interpretadas como parte do 'embasamento' (e.g. Fernandes et al. 1992b, p. 196-7). Tais interpretações, que se baseavam fundamentalmente na classificação das rochas para inferir sua génese e não na sua estratigrafia e relações de campo, carregam resquícios da influência geognóstica, tão comum no estudo do Escudo Sul-rio-grandense no início do século. Segundo essa concepção, a classificação da rocha determinava a sua posição estratigráfica. Assim, todos os granitos deveriam pertencer à crosta primitiva e, os gnaisses, à primeira camada imediatamente superposta, seguida pelos xistos, denominados de rochas de transição. Facilmente correlacionava-se, então, os xistos do Porongos com os da Série de Minas, como tendo sido gerados num mesmo evento ( $c f$. Menegat 1992). Claro está que essas concepções foram superadas pelo fato de que a idade relativa das rochas não pode ser determinada pela sua classificação e, sim, por suas relações estratigráficas de campo. Este critério remonta aos primórdios da história da geologia, visto ter sido utilizado por James Hutton (1795) para refutar as teses neptunistas de Werner, sendo um marco das teorias empiricamente testáveis em relação às concepções meta-físicas então em voga.

Fatores associados à predominância de sequências sedimentares maturas de águas rasas, ausência ou inexpressividade de associações de rochas típicas de crosta oceânica e retrabalhamento de rochas do embasamento são características que seguramente contribuíram para reforçar as concepções tectônicas ensiálicas. No entanto, estas feições, bastante semelhantes às descritas para o domínio geofísico central, não são representativas para o Cinturão Dom Feliciano como um todo, nem suficientes como diagnosticas de um modelo ensiálico. Isso em função da possibilidade de que parte desse 'cinturões de xistos' constituam-se em associações de rochas depositadas em bacias restritas e mais novas, como brevemente discutido no final do item 4 -Parte I).

A importância de uma cronologia de eventos, aparentemente longa, possível de ser estabelecida a partir dos dados disponíveis do CDF (cf. Tabs. la-d) em termos da existência de mais de um cinturão orogênico no escudo não deve, contudo, ser subestimada. Enquanto que as diferentes idades 
radiométricas disponíveis para as distintas porções oriental e ocidental do mesmo não possuem consistência geológica de comparação, visto serem obtidas por métodos de acuracidade e precisão diferentes, o mesmo não se verifica para aquelas provenientes de cada domínio (E ou W). Ao comparar-se as datações, obtém-se uma cronologia de eventos excessivamente longa, mesmo se comparadas a outros cinturões préCambrianos. Enquanto a comparação dessa cronologia entre os diferentes domínios pode ser questionada pelo fato de que a maioria absoluta das idades serem advindas da datação de rochas graníticas pelo método $\mathrm{Rb} / \mathrm{Sr}$, o mesmo não pode ser afirmado em relação às diferenças de idades no interior de cada domínio. Nesses, as diferenças de idades U/Pb entre os granitóides orogênicos da associação de Arco Magmático II ( $c f$. $\mathrm{Tab} . \mathrm{Ib}$ ) e as $\mathrm{Rb} / \mathrm{Sr}$ dos granitóides pós-tectônicos dessa região (e.g. respectivamente $568 \mathrm{Ma}$-Complexo Granítico Santo Afonso, Soliani Jr. 1986) mantém uma diferença da ordem de dezenas de milhões de anos e não podem ser atribuídas à modificações por processos metamórfíco-deformacionais mais jovens ou à falta de acuracidade dos métodos. Desse modo, a possibilidade de que este cinturão apresente uma cronologia anormalmente longa de eventos responsáveis pela sua estruturação deve ser sistematicamente testada. Isso devido ao fato de que há uma chance diminuta de que as associações de rochas, como os granitóides cálcio-alcalinos e os pós-tectônicos, em cada uma das regiões (E e W) do escudo, tenham sido formados em zonas orogênicas (sensu Sengör 1991) de idades marcadamente diversas, cénica situação que poderia justificar a proposição de tratarem-se de diferentes cinturões orogênicos.

CONCLUSÕES Parece ser claro que a metodologia atualista de construção de modelos geotectônicos, enunciada em termos da relação entre o reconhecimento de associações petrotectônicas e suas diferentes possibilidades interpretativas apresenta diversas vantagens, dentre as quais a possibilidade de hierarquizar os eventos reconhecidos tanto em termos de sua cronologia, quanto da sua distribuição espacial no cinturão orogênico. Dada a complexidade do registro geológico no Escudo Sul-rio-grandense, uma quantidade muito grande de arranjos sincrônicos e diacrônicos do registro podem ser feitos, ainda mais se considerarmos as disparidades possíveis e inerentes aos métodos analíticos, como por exemplo, os geocronológicos. Se considerarmos que não há nenhuma possibilidade de hierarquizar registros geológicos que estruturem as demais funções, correremos o risco de atribuir maior valor à parte do que ao todo. Isso poderia significar que qualquer base de dados é suficiente para a proposição de um modelo, como tem sido verificado na literatura. No entanto, essa metodologia, por não promover a testabilidade dos modelos geológicos, acarreta na proposição de modelos altamente especulativos e sem capacidade de predição. Por outro lado, se considerarmos que os registros geológicos podem ser hierarquizados em termos de domínios delimitados por descontinuidades, com a melhoria gradativa da precisão e realismo, pode-se obter modelos mais consistentes. Ora, os domínios definidos em termos de associações petrotectônicas testadas por dados geológicos e geofísicos ( $c f$. Parte II) e vice-versa, permitem considerar as suas unidades litológicas como sendo geneticamente relacionadas. Isto implica em formas específicas de estabelecer a sua estratigrafia e correlação, possibilitando testar-se o modelo que as prediz como sendo geneticamente relacionadas, segundo escalas espaço-temporais comuns.

Outro ponto importante, que emerge dessa discussão, diz respeito aos fatores responsáveis pelas diferenças (reais e aparentes) entre os modelos tectônicos propostos para a evolução da crosta continental do Escudo Sul-rio-grandense durante o Ciclo Brasiliano, denotados em termos da ausência continuada de informações geológicas inter-relacionadas e sistemáticas. Isso é particularmente crítico na obtenção de dados geocronológicos, não apenas em função da importância do controle geológico-estratigráfico para a sua adequada interpretação, mas também para possibilitar a recuperação dos mesmos sob a luz dos avanços no conhecimento geológico. $\mathrm{O}$ que se está propondo não é a elegia de uma ou outra concepção geotectônica, mas que o teste de modelos seja possível de ser efetuado através da aplicação sistemática de diversas técnicas em rochas, cuja natureza, evolução e posição estratigráfica sejam razoavelmente bem conhecidas. Essa postura epistemológica foi claramente enunciada por Popper (1982) ao

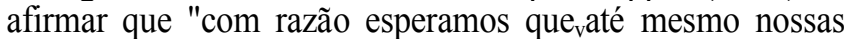
teorias sejam substituídas por outras, ainda melhores (...). Isso, contudo, não nos deve induzir 'a atitude de elaborar teorias apenas para que sejam substituídas".

Agradecimentos Os autores agradecem ao $\mathrm{CNPq}$ pela concessão de bolsas de Pesquisa (Proc.n ${ }^{0}$ 200.858/82), Pósgraduação e auxílios e, ao Instituto de Geociências/UFRGS pelo apoio logístico durante os Trabalho de Graduação (19881994), que resultaram na realização de alguns dos mapas apresentados. Agradecemos, ainda, aos bolsistas Vilmar R. da Silva, pelo trabalho gráfico de grande parte das figuras, Leondres D. de Oliveira e Luciana Félix, pelo auxílio com a lista de referências bilbiográficas. Aos Professores B.B. de BritoNeves e H, Jost agradecemos respectivamente, o incentivo à apresentação do trabalho e a boa vontade e esforços para a editoração do mesmo, apesar da exiguidade dos prazos.

\section{REFERÊNCIAS}

ALLÈGRE, C. 1988. A espuma da terra, Lisboa, Gradiva, 399p.

BABINSKY, M.; CHEMALE JR.R; HARTMANN, L.A.; VAN SCHUMUS, W.R.; DA SILVA, L.C. 1995. Acresção juvenil no Bloco São Gabriel e retrabalhamento crustal no Cinturão Dom Feliciano durante o Ciclo Brasiliano: Evidências isotópicas. IN: SIMPÓSIO SULBRASILEIRO DE GEOLOGIA, 6, Encontro de Geologia do Cone Sul.,1. Porto Alegre, 1995. Atas... Porto Alegre, SBG. p.105-107.

BABINSKY, M.; CHEMALE JR.F.; HARTMANN, L. A.; VAN SCHUMUS, W.R.; DA SILVA, L.C. 1996. Juvenile accretion at 750$700 \mathrm{Ma}$ in Southern Brazil. Geology, 24:439-442.

BACHELARD, G. 1934. Lê Nouveal EspiritScientifique. Paris, Puf.

B ADIOU, A. 1989. Sobre o conceito de modelo. São Paulo, Mandacaru. 130 $\mathrm{P}-$
BASEI, M.A.S. 1985. O Cinturão Dom Feliciano em Santa Catarina. São Paulo. 196p. (Tese de doutorado em Geociências, Universidade de São Paulo).

BEURLEN, K. \& MARTINS, E.A. 1956. O Escudo Sul-Rio-Grandense: Conceito Geológico e paleogeográfico. Boletim do Museu Nacional, Rio de Janeiro, 23:1-25.

BOSSI, J. \& CAMPAL, N. 1992. Magmatismo y tectónica transcurrente durante el Paleozóico Inferior en Uruguay. IN: GUTIÉRREZ MARCO, J.G.; SAAVEDRA \& RÁBANO, eds. Paleozóico Inferior de IberoAmérica. Espanha, Universidade de Extremadura. p. 343-356.

BRANNER, J.C. 1919. Outlines of the Geology of Brazil to accompany the geologic map of Brazil. Bullettin of Geological Society of America, 30(2): 189-328. 
CARVALHO, P.F. 1932. Reconhecimento geológico do Rio Grande do Sul. Inst. Geol. Min. Brás., Rio de Janeiro, Boletim 66:1-72.

CHEMALE JR. R; GRESSE, P.; DA SELVA, L.C.; HARTMANN, L.A.; WALRAVEN, F. 1995b. Correlação geológica entre as unidades Brasilianas e Panafricanas do Sul do Brasil e África do Sul. IN: SIMPÓSIO SUL-BRASILEIRO DE GEOLOGIA, 6, Encontro de Geologia do Cone Sul, 1. Porto Alegre, 1995. Atas... Porto Alegre, SBG. p.13-16.

CHEMALE JR., F.; HARTMANN, L.A.; BABINSKI, M.; WILDNER, W.; V AN SCHMUS, W.R. 1994. Evolução tectônica do bloco São Gabriel. IN: CONGRESSO BRASILEIRO DE GEOLOGIA, 38. Balneário Camboriú, 1994. Boletim de Resumos Expandidos... Balneário Camboriú, SBG. v.l, p.232-233.

CHEMALE JR., F.; HARTMANN, L.A.; DA SILVA, L.C. 1995a. Stratigraphy and Tectonism of Precambriam to early Paleozoic units in Southern Brazil and Uruguay. Acta Geológica Leopoldênsia, 44:1-111.

CHEMALE JR., F.; HARTMANN, L.A.; DA SILVA, L.C. 1996. Stratigraphy and Tectonism of Brasiliano Cycle in Southern Brazil. IN: MCNIALL, M. ed. Proceedings volume on Proterozoic Crust \& metallogenetic evolution. Geológica! Society of Namíbia (in press).

CORDANI, U.G. 1968. Esboço de geocronologia pré-cambriana da América do Sul. IN: SIMPÓSIO SOBRE O MANTO SUPERIOR., An. Acad. Brás. Ciênc, Rio de Janeiro, 40:47-51.

COSTA, A.F.U. \& CALDASSO, A.L.S. 1994. Padrões do campo magnético aplicados à geologia estrutural na região de Pinheiro Machado-RS. IN: CONGRESSO BRASILEIRO DE GEOLOGIA, 38. Balneário Camboriú, 1994. Boletim de Resumos Expandidos... Balneário Camboriú,SBG. v.2,p.31-32.

COWARD, M.P. 1980. Shear zones in the Precambrian crust of Southern África. Journal ofStructural Geology, 2: 19-28.

COWARD, M.P. \& DALY, M.C. 1984. Crustal lineaments and shear zones in África: their relationship to plate movements. Precambrian Research, 24:27-45.

DALY, M.C. 1988. Crustal shear zones in Central África: a kinematic approach to Proterozoic tectonics. Episodes, 11:5-11.

FERNANDES, L.A.D.; KRAEMER, G.; TOMMASI, A.; PORCHER, C.C.; COSTA, A.F.U.; MENEGAT, R.; KOESTER, E. 1996. Evolução tectônica do pré-Cambriano da região de Lavras do Sul. Pesquisas (no prelo).

FERNANDES, L.A.D.; TOMMASI, A.; KRAEMER, G.; KOESTER, E.; SCHERER, C.M.S. 1994. Outline of the tectonic evolution of part of the Magmatic Are Assemblage II: The 'Cambai Complex' of Lavras do Sul (RS). IN: CONGRESSO BRASILEIRO DE GEOLOGIA, 38. Balneário Camborioe, 1994. Boletim de Resumos Expandidos... Balneário Camboriú, SBG. v.l, p.256-258.

FERNANDES, L.A.D.; TOMMASI, A.; PORCHER, C.C. 1990. Esboço estrutural de parte do Batólito Pelotas-região de Quitéria-Capivarita. Acta Geológica Leopoldênsia, 30:117-138.

FERNANDES, L.A.D.; TOMMASI, A.; PORCHER, C.C. 1992a. Deformation Patterns in the Southern Brazilian Branch of the Pan-African Dom Feliciano Belt. Journal of South American Earth Sciences, 5:77-96.

FERNANDES, L.A.D.; TOMMASI, A.; PORCHER, C.C.; KOESTER, E.; KRAEMER, G.; SCHERER, C.M.; MENEGAT, R. 1992b. Granitóides Precoces do Cinturão Dom Feliciano: Caracterização Geoquímica e Discussão Estratigráfica. Pesquisas, 19 (2): 197-218.

FERNANDES L.A.D.; TOMMASI, A.; PORCHER, C.C.; MENEGAT, R. 1991. Correlação estrutural cinemática em faixas móveis: Uma discussão. IN: SIMPÓSIO NACIONAL DE ESTUDOS TECTÔNICOS, 3. Rio Claro, 1991. Boletim de resumos... Rio Claro, SBG. p.166-168.

FERNANDES, L.A.D.; TOMMASI, A; VAUCHEZ, A.; PORCHER, C.C.; MENEGAT, R.; KOESTER, E. 1993. Zona de cisalhamento transcorrente Dorsal de Canguçu: Caracterização e importância na compartimentação tectônica do Cinturão Dom Feliciano. Revista Brasileira de Geociências, 23(2): 1-10.

FIGUEIREDO, M.C.H.; FRAGOSO CÉSAR, A.R.S.; KRONEBERG, B.I. 1990. Litoquímicadas principais unidades do Batólito de Pelotas no Rio Grande do Sul. IN: CONGRESSO BRASILEIRO DE GEOLOGIA, 36. Belém, 1990. Boletim de Resumos Expandidos... Belém, SBG. v.4, p.1726-1738.

FRAGOSO-CÉSAR, A.R.S. 1980.0 Cráton do Rio de La Plata e o Cinturão Dom Feliciano no Escudo Uruguaio Sul-riograndense. IN: CONGRESSO BRASILEIRO DE GEOLOGIA, 31. Balneário de Camboriú, 1980. Anais... Balneário de Camboriú, SBG. v.5, p.2879-2892.

FRAGOSO-CÉSAR, A.R.S. 1991. Tectônica de placas no Ciclo Brasiliano: As orogenias dos Cinturões Dom Feliciano e Ribeira no Rio Grande do Sul. São Paulo. 367 p.(Tese de Doutorado em Geociências, Universidade de São Paulo).
FRAGOSO-CÉSAR, A.R.S.; \& SOLIANI JR., E. 1984. Compartimentação tectônica do cráton Rio de Ia Plata. /M CONGRESSO BRASILEIRO DE GEOLOGIA, 33. Rio de Janeiro, 1984. Anais... Rio de Janeiro, SBG. v: 5, p. 2426-2432.

FRAGOSO-CÉSAR, A.R.S.; FIGUEIREDO, M.C.H.; SOLIANI JR., E.; FACCINI, U.F. 1986. O Batólito Pelotas (Proterozóico Superior/ Eo-Paleozóico) no Escudo do Rio Grande do Sul. IN: CONGRESSO BRASILEIRO DE GEOLOGIA, 38. Goiânia, 1986. Anais... Goiânia, SBG. v.3,p.!322-1342.

FRAGOSO-CÉSAR, A.R.S.; LAVINA, E.L.; PAIM, P.S.; FACCINI, U.F. 1984. A antefossa molássica do cinturão Dom Feliciano no estado do Rio Grande do Sul. IN: CONGRESSO BRASILEIRO DE GEOLOGIA, 33. Rio de Janeiro, 1984. Anais... Riode Janeiro, Sbg. v.7,p.3272-3283.

FRAGOSO-CÉSAR, A.R.S.; MACHADO, R.; MELLO, F.M.; SAYEG, H.S.; SILVA P, W.F.; FAMBRINI, G.L. 1994. Acresção neoproterozóica no sul do Brasil e Uruguai: A placa Rio de La Plata e os terrenos Piratini e Rio Vacacaí. IN: CONGRESSO BRASILEIRO DE GEOLOGIA, 38. Balneário de Camboriú, 1994. Boletim de Resumos Expandidos... Balneário de Camboriú; SBG. v.l, p.206-207.

FRAGOSO-CÉSAR, A.R.S.; MACHADO, R.; WERNICK, E.; MCREATH, L; PHILLIP, R.P.; SALLET, R.; ENDO, I.; MELLO, F.M.; ALMEIDA, T.R.I.; SAYEG, H.S.; FAMBRINI, G.L.; SILVA P, W.F.; DEHLER, N.M.; TEIXEIRA, A.L. 1995. The Braziliania Plate, the Western Paranaides and the Eastern Atlantides and África model for the Neoproterozoic Tectonic collage of Southeastern South America. IN: SIMPÓSIO SUL-BRASILEIRO DE GEOLOGIA, 6, Encontro de Geologia do Cone Sul, 1. Porto Alegre, 1995. Atas... Porto Alegre, SBG. p.20-25.

FRAGOSO-CÉSAR, A.R.S.; WERNICK, E.; SOLIANI JR., E. 1982. Evolução geotectônica do Cinturão Dom Feliciano - uma contribuição através da aplicação do modelo de Tectônica de Placas. IN: CONGRESSO BRASILEIRO DE GEOLOGIA, 32. Salvador, 1982. Anais... Salvador, SBG. v.l, p.13-23.

FRANTZ, J.C. \& FERNANDES, L.A.D. 1994. "Granitóides Tardi- a Pósorogênicos do Ciclo Brasiliano no Cinturão Dom Feliciano-RS". IN: CONGRESSO BRASILEIRO DE GEOLOGIA, 38. Balneário de Camboriú, 1994. Boletim de Resumos Expandidos... Balneário de Camborio;, SBG. v.l, p.150-152.

FRANTZ, J.C. \& NARDI, L.V.S. 1992a. Litoquímica e evolução dos granitóides cálcio-alcalinos da Região Leste do Escudo Sul-rio-grandense. Pesquisas, 19(1): 13-25.

FRANTZ, J.C. \& NARDI, L.V.S. 1992b. O magmatismo granítico da região oriental do Escudo Sul-rio-grandense: Uma revisão. Pesquisas 19(2): 183-189.

FRANTZ, J.C.; LIMA, E.F.; MACHADO, R.P.; NAUMANN, M.P. 1984. Contribuição à geologia da região de Encruzilhada do Sul -RS. IN: CONGRESSO BRASILEIRO DE GEOLOGIA, 33. Rio de Janeiro, 1984. Anais... Rio de Janeiro, SBG. v.5, p.2407-2416.

GONI, J.C. 1962. Origine dês roches ultrabasiques et serpentineuses du Pré-Cambrien de Rio Grande do Sul (Brésil). Mode de gisement et mineralization. Boletim da Escola de Geologia da UFRGS. Porto Alegre, 12: 1-89.

HARTMANN, L.A. 1987. Isócrona Sm-Nd de 2,1 Ga em minerais de duas amostras do Complexo Granulítico Santa Maria Chico, RS. IN: Congresso Brasileiro de Geoquímica, 1. Porto Alegre, 1987. Anais... Porto Alegre, SBG. v.l, p.105-111.

Hartmann, L.A. \& NARDI, L.V.S. 1983. contribuição à geologia da região oeste do escudo sul-riograndense. IN: SIMPÓSIO SUL-BRASILEIRO DE GEOLOGIA, 1. Porto Alegre, 1983. Atas... Porto Alegre, SBG. p.9-18.

HARTMANN, L.A. ; CHEMALE JR., F.; DA SILVA, L.C. 1994. Mantle plume tectonics in the Brasiliano Cycle of the Dom Feliciano Belt, Southern Brazil. /M CONGRESSO BRASILEIRO DE GEOLOGIA, 38. Balneário de Camboriú, 1994. Boletim de Resumos Expandidos... Balneário de Camborice, SBG.v.l, p.623.

HASUÍ, Y.; CARNEIRO, C.D.R.; COIMBRA, A.M. 1975. The Ribeira folded belt. Revista Brasileira de Geociencias, 5(4):257-267.

HATTIN, D.E. 1991. Lithodemes, suites, supersuites, and complexes: intrusive, metamorphic, and genetically mixed assemblages of rocks now embraced by North American Code of Stratigraphic Nomenclature. Precambrian Research, 50:355-357.

HESSE, M. 1965. The explanotory function of metaphor. Bar-Hillel, Y. LOGIC AND PHILOSOPHY OF SCIENCE. Proceedings of the 1964 International Congress. Amsterdam, North-Holland Pub. Co, 249-259.

HILDE, T.W.C. \& CARLSON, R.L.(eds) 1991. Silver Anniversary of Plate Tectonics. Tectonophysics, 187:1-344. 
HOPGOOD, A.M. 1984. Structural evolution of Svecokarelian migmatites, southern Finland: a study of Proterozoic crustal development. Transaction of the Royal Society of Edinburgh. Earth Sciences, 74:229-264.

HUTTON, J. 1795. Theory of the Earth. Transactions ofthe Royal Society of Edinburg, 1:209-305.

JOST, H. 1981. Geology and metallogeny of the Santana da Boa Vista Region, Southern Brazil. Georgia. 208p. (Doctor of Philosophy Thesis, University of Georgia).

JOST, H. \& BITENCOURT, M.F.A.S. 1980. Estratigrafia e tectônica de uma fração da Faixa de Dobramentos Tijucas no Rio Grande do Sul. Acta Geológica Leopoldensia, 15:27-60.

JOST, H.\& VILLWOCK, J.A. 1966. Contribuição à estratigrafia do PréCambriano no Rio Grande do Sul. Notas e Estudos. Escola de Geologia, UFRGS, Porto Alegre, 1(1): 13-26.

KAALSBEEK, F.; PIDGEON, R.T.; TAYLOR, P.N. 1987. Nagssugtoqidian mobile belt of West Greenland: a cryptic 1850 Ma suture between two Archaean continents -chemical and isotopic evidence. Earth Planetary Science Letters, 85: 365-385.

KAALSBEEK, F \& NUTMAN, A.P. 1996. Anatomy ofthe Early proterozoic Nagssugtoqidian orogen, West Greenland, explored by recognnaissance SHRIMP U/Pb zircon dating. Geology, 24:515-518.

KENNEDY, W.Q. 1964. The structural differentiation of África in the Pan-African ( \pm 550 m.y.) tectonic episode. Research Institute ofAfrican Geology, University ofLeeds Sth Annual Report, 48p.

KOESTER, E. 1995. Evolução geológica do magmatismo sintectônico à Zona de Cisalhamento Transcorrente Dorsal de Canguçu, região de Encruzilhada do Sul (RS). Porto Alegre. 240 p. (Dissertação de Mestrado em Geociências, Universidade Federal do Rio Grande do Sul).

KOESTER, E.; TOMMASI, A.; SOLIANI JR., E.; FERNANDES, L.A.D.; KRAEMER; G. 1994. Evolução geológica do magmatismo sintectônico à Zona de Cisalhamento Transcorrente Dorsal de Canguçu (RS): dados $\mathrm{Rb} / \mathrm{Sr}$. IN: CONGRESSO BRASILEIRO DE GEOLOGIA, 38. Balneário Camboriú, 1994. Boletim de Resumos Expandidos... Balneário Camboriú, SBG. v.2, p.383-384.

KOESTER, E.; SOLIANI JR., E.; FERNANDES, L.A.D. NARDI, L.V.S.; KRAMER.G. 1995. Posicionamento de granitóides cálcico-alcalinos e peraluminosos sintectônicos à Zona de Cisalhamento Transcorrente Dorsal de Canguçu, Encruzilhada do Sul, RS. IN: Simpósio Nacional de Estudos Tectônicos, 5. Gramado, 1995. Boletim de Resumos Expandidos... Gramado, SBG. p.197-198.

KOESTER, E; SOLIANI JR, E; KRAEMER, G; FERNANDES, L.A.D; TOMMASI, A. 1996. Geocronologia dos granitóides sintectônicos à Zona de Cisalhamento Transcorrente Dorsal de Canguçu (RS). Pesquisas, (submetido).

KRAEMER, G. 1995. Evolução magmática e tectônica da Suite Ortometamórfica Imbicuí, região de Lavras do Sul (RS). Porto Alegre. 99p. (Dissertação de Mestrado em Geociências, Universidade Federal do Rio Grande do Sul).

KRAEMER, G.; FERNANDES, L.A.D.; KOESTER, E.; TOMMASI, A. 1993b. Evolução Geológica do Complexo Cambai na Região de Lavras do Sul, RS. IN: SIMPOSIO SUL-BRASILEIRO DE GEOLOGIA, 5. Curitiba, 1993. Boletim de Resumos... Curitiba, p.7-8.

KRAEMER, G.; FERNANDES, L.A.D.; TOMMASI, A.; KOESTER, E. 1993a. Petrologia das rochas Plutônicas Metamorfisadas da Região de Lavras do Sul: Dados Preliminares. IN: SIMPÓSIO INTERNACIONAL DEL NEOPROTEROZOICO-CAMBRICO DE LA CUENCA DEL PLATA, 1. La Paloma, 1993. Anais... La Paloma-Minas. v.2(36), $3 p$.

KRÖNER, A. 1981. (ed.). Precambrian Plate Tectonics. Elsevier, Amsterdam, $570 \mathrm{p}$

KRÖNER, A. 1991. Tectonic evolution in the Archaean and Proterozoic. Tectonophysics, 187:393-410.

KUHN, T.S. 1989. A estrutura das revoluções cientificas, [trad. do ing. The structure of scientific revolution, 1962 por B.V. Boeira e N. Boeira]. São Paulo, Perspectiva. 257 p., 3 ed. (Coleção Debates, n. 115).

KUKLA, P.A. \& STANISTREET, I.G. 1991. Record of the Damaram Khomas Hochland accretionary prism in central Namíbia: Refutation of an "ensialic" origin of a Late Proterozoic orogenic belt. Geology, 19: 473-476.

LAKATOS, I. 1974. Falsifications and methodology of scientific research programmes. IN: LAKATOS, I. \& MUSGRAVE, A. eds. Criticism and the growth of knowledge. Cambridge, Cambridge University Press.

LAKATOS, I. 1979. O falseamento e a metodologia dos programas de pesquisa científica. IN: LAKATOS, I. \& MUSGRAVE, A: eds. $A$ Crítica e o Desenvolvimento do Conhecimento, [trad. do ing. Criticism and the growth ofknowledge por O. M. Cajado, ed. 1970]. São Paulo, Cultrix, EDUSP.
LAKATOS, 1.1987. Matemáticas, ciência y epistemología [trad. ing. Mathematics, science and epistemology -philosophical papers, vol. 2, 1978, por D. R. Nicolás]. Madri, Alianza Editorial. Ia reimp., 360 p.

LAKATOS, I. 1993. La metodolígia de los programas de investigación cientifica. Madrid, Alianza Universidad. 315 p.

LEINZ, V.; BARBOSA, A.F.; TEIXEIRA, E.A. 1941. Mapa Geológico Caçapava-Lavras. Boletim da Diretoria da Produção Mineral, Porto Alegre, 90:1-39.

LEITE, J.A.D.; MACNAUGHTON, N.J.; HARTMANN, L.A.; CHEMALE JR.,F.; REMUS, M.V.D. 1995a. SHRIMP U/Pb zircon datting applied to the determination of tectonic events: The example of Cacaçapava do Sul Batholith, Pedreira Inducal, Caçapava, Brazil. IN: SIMPÓSIO NACIONAL DE ESTUDOS TECTÔNICOS, 5. Gramado, 1995. Boletim de resumos Expandidos... Gramado, SBG. p.387-388.

LEITE, J.A.D.; MACNAUGHTON, N.J.; HARTMANN, L.A.; CHEMALE JR..F. 1995b. Age and tectonic setting of metabasalts and metagranitoids from the Cerro Mantiqueiras region: Evidences from shrimp U/pb zircon dating and $\mathrm{pb} / \mathrm{pb}$ isotopes. IN: SIMPÓSIO NACIONAL DE ESTUDOS TECTÔNICOS, 5. Gramado, 1995. Boletim de resumos expandidos... Gramado, SBG. p.389-390.

LUZARDO, R \& FERNANDES, L.A.D. 1990. Análise estrutural do Lineamento de Ibaré. Acta Geológica Leopoldensia, 13:25-36.

MACGREGOR, A.M. 1951. Some milestones in the Precambrian of Southern Rhodesia. Proceedings ofthe Geological Society of South Africa, 54: $27-71$.

MANDELBROT, B. 1977. The fractal geometry of nature. New York, Freeman, 279p.

MANTOVANI, M.S.M.; HAWKESWORTH, C.J.; BASEI, M.A.S. 1987. $\mathrm{Nd}$ and $\mathrm{Pb}$ isotope studies bearing on the crustal evolution of Southeastern Brazil. Revista Brasileira de Geociências, 17:263-268.

MARQUES, J.C. 1996. Faciologia e evolução estrutural da porção NE da Suite Metamórfica Porongos no Escudo Sul-rio-grandense. Porto Alegre. (Dissertação de Mestrado em Geociências, Universidade Federal do Rio Grande do Sul, em preparação).

MENEGAT, R. 1992. Das minas de cobre e carvão ao modelo de colisão continental. Contribuição ao estudo da mutação epistemológica dos modelos do pré-Cambriano do Escudo Sul-rio-grandense (1823 a 1990). Porto Alegre. 308p. (Dissertação de Mestrado em Geociências, Universidade Federal do Rio Grande do Sul).

MENEGAT, R. 1994. Modelos, ciência e verdade. IN: REUNIÃO BRASILEIRA DE MANEJO E CONSERVAÇÃO DO SOLO E DA ÁGUA, 10. Florianópolis, 1994. Resumos... Florianópolis, v.1, p.79-85.

MENEGAT, R. \& FERNANDES, L.A.D. 1992. The black-box technique: characteristics of a scientific problem in geology. IN: CONGRESSO BRASILEIRO DE GEOLOGIA, 37. São Paulo, 1992. Boletim de resumos expandidos... São Paulo, SBG. v.2, p.250-251.

MENEGAT, R. \& FERNANDES, L.A.D. 1993a. Methodology of science in geology: characterization through the aplication ofthe black-box technique. IN: INTERNATIONAL CONFERENCE ON GEOSCEENCE EDUCATION AND TRAINING, Annals... Southampton (UK), Association of Geoscientists for International Development (AGID), International Union of Geological Sciences (IUGS), University of Southampton. p. 1-3.

MENEGAT, R. \& FERNANDES, L.A.D. 1993b. A evolução dos modelos geológicos do pré-Cambriano do Escudo Sul-Rio-grandense entre 1823 e 1990. IN: SIMPÓSIO SUL-BRASILEIRO DE GEOLOGIA, 5. Curitiba, 1993. Boletim de Resumos e Programa... Curitiba, SBG. v.l, p.11-13.

MENEGAT, R. \& FERNANDES, L.A.D. 1995. O método da investigação científica na Geologia. Revista Brasileira de Geociências, 24(3): 1-26.

MENEGAT, R. \& FERNANDES, L.A.D. 1996. Historiografia da Geologia no Brasil e no Rio Grande do Sul: breve comentário sobre seus métodos e protagonistas. Porto Alegre, Episteme, 2:111-122.

MYERS, J.S. \& KRÓNER, A. 1994. Archean tectonics. In Hancock, P.L. ed. Continental Deformation. Oxford, Pergamon Press. p. 355-369.

PEACH.B.N.; HORNE.J.; GUNN.W.; CLOUGH.C.T.; HINXMAN.L.W.; TEALL, J.J.H. 1907. "The geological structure of he north-west highlands ofScotland". Mem.Geol.Surv.Great Britain.

PHILIPP, R.P. 1991. Geologia dos granitóides da região de Monte Bonito, Pelotas. Acta Geológica Leopoldensia, 14(33): 71-128.

PLATT, J.P.1990. Exhumation of high-pressure rocks: A review of concepts and processes. Terra Nova, 5:119-133.

POPPER, K.R. 1989. A lógica dapesquisa cientifica. [Trad. do ing. The logic of scientific discovery por L. Hegenberg e e O.S. da Mota, ed. 1972]. São Paulo, Cultrix. 4ed., 567 p.

POPPER, K.R. 1982. Conjecturas e refutações. Brasília, Universiade de Braseilia. 449 pp., 2 a ed. 
PORADA, H. 1979. The Damara-Ribeira orogen of the Pan-African-Braziliano Cycle in Namibia (Southwest África) and Brazil as interpreted in terms of continental collision. Tectonophysics, 57:237-265.

Porcher, C.C. 1992. Caracterização das condições defluxo em uma zona de cisalhamento tangencial na região de Santana da Boa Vista (RS). Porto Alegre. 192 p. (Dissertação de Mestrado em Geociências, Universidade Federal do Rio Grande do Sul).

PORCHER, C.C. \& FERNANDES, L.A.D. 1990. Relacões embasamento/ cobertura na porção ocidental do Cinturão Dom Feliciano: um esboço estrutural. Pesquisas, 17:72-84.

PORCHER, C.C. \& FERNANDES, L.A.D. 1992. Determinação das condições de fluxo em uma zona de cisalhamento tangencial com transporte paralelo ao alongamento do cinturão Dom Feliciano (RS) com base na análise de microestruturas. IN: CONGRESSO BRASILEIRO DE GEOLOGIA, 37. São Paulo, 1992. Boletim de resumos expandidos... São Paulo, SBG. v.2, p.352-353.

PORCHER, C.C. \& FERNANDES, L.A.D. 1993. Evidências de uma Zona de Cisalhamento com transporte longitudinal na Associacão de Bacia Marginal do Cinturão Dom Feliciano no Rio Grande do Sul - Brasil. IN: SIMPÓSIO INTERNACIONAL DEL NEOPROTEROZÓICO-CAMBRICO DE LA CUENCA DEL PRATA, 1. Lãs Palomas, 1993. Boletim de Resumos Expandidos... Lãs Palomas-Minas. v. 1(24), p.7.

PORCHER.C.C; FERNANDES, L.A.D. \& MONTEIRO, A.0.1995. Zoneamento metamórfico das granadas e dados de geotermometria dos metamorfitos Cerro do Facão - Suíte Metamórfica Porongos (RS). IN: SIMPÓSIO NACIONAL DE ESTUDOS TECTÔNICOS, 5. Gramado, 1995. Boletim de resumos Expandidos... Gramado, SBG. p.69-70.

PRIGOGINE, Y. \& STENGERS, I. 1991. A nova aliança, [trad. do fr. La nouvelle alliance; métamorphose de Ia science,. 1984, por M. Faria e M.J.M. Trincheira.]. Brasília, Ed. da Universidade de Brasília. 247 p., led.

REMUS, M.V.D. 1990. Geologia e geoquímica do Complexo Cambaizinho, São Gabriel (RS). Porto Alegre. 267p. (Dissertação de Mestrado, Universidade Federal do Rio Grande do Sul).

REMUS, M.V.D.; MCNAUGHTON, N.J.; HARTMANN, L.A.; GROVES, D.1.1995. The oldest magmatic rock from the São Gabriel Block of the Sul-rio-grandense Shield, Southern Brazil, identified by U/Pb dating of zircons using SHRIMP. IN: AUSTRALIAN CONFERENCE ON GEOCHRONOLOGY AND ISOTOPE SCIENCE., Perth, 1995. Extended Abstracts... Perth, p.l.

REMUS, M.V.D.; MCNAUGHTON, N.J.; HARTMANN, L.A.; GROVES, D.I. 1996. IN: SYMPOSIUM ON ARCHAEAN TERRANES OFTHE SOUTH AMERICAN PLATAFORM. Brasília, 1996. Extended Abstracts... Brasília, SBG. p.67-70.

RIBEIRO, M. \& FANTINEL, L.M. 1978. Associações petrotectônicas do Escudo Sul-riograndense: I Tabulação e distribuição das associações petrotectônicas do Escudo do Rio Grande do Sul. Iheringia, Série Geológica, 5:19-54.

SANTOS, E.L.; RAMGRAB, G.E.; MACIEL, L.A.; MOSMANN, R. 1989 Mapa Geológico do Estado do Rio Grande do Sul. DNPM, $1^{\circ}$ Distrito Regional.

SENGÖR, A.M.C. 1990. Plate tectonics and orogenic research after 25 years: synopsis of a Tethyan perspective. Earth Science Reviews, 27:1-201.

SENGÖR, A.M.C. 1991. Plate tectonics and orogenic research after 25 years: synopsis of a Tethyan perspective. Tectonophysics, 187: 315-344.

SENGÖR, A.M.C. \& Dewey, J.F. 1990. Terranology: Vice or virtue ? Transaction Royal Socieíy London A 331:1-21.

SHACKLETON, R.M. \& RIES, A.C. 1984. The relation between regionally consistent stretching lineations and plates motions. Journal ofStructural Geology, 6: 111-120.

SHUKOWSKY, W.; VASCONCELOS, A.C.B.C.; MANTOVANI, M.S.M 1991. Estruturação dos terrenos pré-cambrianos da região sul do Brasil e oeste do Uruguay, e sua continuidade sob os sedimentos da Bacia do Paraná: Um estudo por modelamento gravimétrico. Revista Brasileira de Geofisica, 9:275-287.

SILVA P, B.C. 1984. Geology of the Polyphase deformed Precambrian Terrane of the Vila Nova Region, State of Rio Grande do Sul, Southern Brazil. Part I: Petrogenesis. Acta Geológica Leopoldensia, 17:35-152.

SILVA P, B.C. 1994. Geology the polyphase deformed precambrian terrane of the vila nova region, state of Rio Grande do Sul, Southern Brazil: Part II: Structural sequence. Acta Geológica Leopoldensia, 14(34):5-94.
SILVA P, B.C. \& SOLIANIJR, E. 1987. Origem e evolução dos gnaisses Cambai: Exemplo de estudo integrado de análise estrutural, petroquímica e geocronológica. IN: SIMPÓSIO SUL-BRASILEIRO DE GEOLOGIA, 3. Curitiba, 1987. Atas... Curitiba, SBG. v.1, p.127-146.

SOHL, N.F. 1977. Note 45- Application for Amendment Concerning Terminology for Igneous and High-Grade metamorphic Rocks. American Association of Petroleum Geologists Bulleiin, 61:248-252.

SOLIANI JR., E. 1986. Os dados geocronológicos do Escudo Sul-rio-grandense e suas implicações de ordem tectônica. São Paulo. 425 p. (Tese de Doutorado em Geociências, Universidade de São Paulo).

SOLIANI JR., E.; FRAGOSO-CÉSAR, A.R.S.; TEIXEIRA, W.; KAWASHITA, K. 1984. Panorama geocronológico da porção meridional do Escudo Atlântico. IN: CONGRESSO BRASILEIRO DE GEOLOGIA, 33. Rio de Janeiro, 1984. Anais... Rio de Janeiro, SBG. v.5, p.2435-2449.

STEGMULLER, W. 1983. Estructura y dinâmica de teorias. Barcelona, Ariel.405p.

SUTTON, J. \& WATSON, J. 1951. The pre-Torridonian History of the Loch Torridon and Scourie Áreas in the North-West Highlands, and its bearing on the chronological Classification of the Lewisian. Quart. J. Geol. Soe. Lona., 106: 241-308.

TESSARI, R.I. \& PICADA, R.S. 1966. Geologia da quadrícula de Encruzilhada do Sul, Rio Grande do Sul, Brasil. Rio de Janeiro, DNPM/DFPM. 124p. (Boletim 124).

THOM, R. 197'5. Structural stability and morphogenesis. Massachussetts, A. Benjamin, Inc. 348 p.

TOMMASI, A. 1991. Evolução cinemática do Cinturão Dom Feliciano durante o Ciclo Brasiliano. Porto Alegre. 207p. (Dissertação de Mestrado, Universidade Federal do Rio Grande do Sul).

TOMMASI, A. \& FERNANDES, L.A.D. 1990.0 ciclo brasiliano na porção sudeste da Plataforma Sul-americana: um novo modelo. IN: CONGRESSO URUGUAYO DE GEOLOGIA, 1. Montevideo, 1990. Anais... Montevideo, v.1, p.107-114.

TOMMASI, A. \& FERNANDES, L.A.D. 1991. Caracterização de um regime tangencial na porção oeste do Escudo Sul-riograndense. IN: SIMPÓSIO NACIONAL DE ESTUDOS TECTONICOS, 4. Rio Claro, 1991. Boletim de Resumos... Rio Claro, SBG. p.128-131.

TOMMASI, A.; FERNANDES, L.A.D.; PINHEIRO-MACHADO, R.; KRAEMER, G.; KOESTER, E. 1994a. Incorporação de Lascas do Manto à Crosta Continental nas porções externas do Cinturão Dom Feliciano-evidências de uma zona de cisalhamento de escala litosférica. Pesquisas, 21(2):79-84.

TOMMASI, A.; FERNANDES, L.A.D.; PORCHER, C.C.; VAUCHEZ, A. 1992. Evolução cinemática das porções internas do Cinturão Dom Feliciano na região de Piratini, RS. Pesquisas, 19(2): 145-156.

TOMMASI, A.; VAUCHEZ, A. FERNANDES, L.A.D.; PORCHER, C.C. 1994b. Magma-assisted strain localization in an orogen-parallel transcurent shear zone of southern Brazil. Tectonics, 132:421-437.

UFRGS 1988. Mapeamento Geológico de parte das folhas de Quitéria e Várzea do Capivarita. Trabalho de Graduacão do Curso de Geologia, Instituto de Geociências da Universidade Federal do Rio Grande do Sul, Porto Alegre.

UFRGS 1991. Mapeamento Geológico de parte das folhas de Lavras do Sul e Coxilha do Tabuleiro. Trabalho de Graduação do Curso de Geologia, Instituto de Geociências da Universidade Federal do Rio Grande do Sul, Porto Alegre.

UFRGS 1992. Mapeamento Geológico deporte das folhas de Encruzilhada do Sul e Delfino. Trabalho de Graduação do Curso de Geologia, Instituto de Geociências da Universidade Federal do Rio Grande do Sul, Porto Alegre.

UFRGS 1993. Mapeamento Geológico de parte das folhas de Cerro da Arvore, Encruzilhada do Sul, Figueiras e Vau dos Prestes. Trabalho de Graduação do Curso de Geologia, Instituto de Geociências da Universidade Federal do Rio Grande do Sul, Porto Alegre.

VAUCHEZ, A. \& NICOLAS, A. 1991. Mountain building: strike-parallel motion and the mantle anisotropy. Tectonophysics, 185:183-201.

WINDLEY, B.F. 1984. The evolving continents. 2ed. New York, Wiley \& Sons, 399p.

MANUSCRITO N $^{\circ}$ A872A

Recebido em 31 de agosto de 1996

Revisão dos autores em 17 de março de 1997 Revisão aceita em 18 de março de 1997 